\title{
EVOLUÇÃO CLIMÁTICA DO GONDWANA NAS REGIÕES CENTRO-SUL DO BRASIL E SEUS REGISTROS GEOLÓGICOS CONTINENTAIS DURANTE O MESOZÓICO, ENFATIZANDO O ARCO DO ALTO PARANAÍBA, A BORDA NNE DA BACIA DO PARANÁ E A PORÇÃO MERIDIONAL DA BACIA SANFRANCISCANA, NO OESTE DO ESTADO DE MINAS GERAIS
}

\author{
Geraldo Norberto Chaves Sgarbi(*) \& Marcel Auguste Dardenne(**)
}

\begin{abstract}
Current theories suggest the the main cause of the temperature changes in Earth surface along the geological time, seems to be, as a concensus, the anomalous concentration of $\mathrm{CO}_{2}, \mathrm{CH}_{4}$ and other gases in the terrestrial atmosphere. There are however divergences about the origin of these gases which are the main responsables for the greenhouse effect.

This study discusses questions about the global climate changes in the geological past, commenting the mass-extinction periods of the Permian-Triassic $(\mathrm{P} / \mathrm{Tr})$ and Cretaceous/Tertiary $(\mathrm{C} / \mathrm{T})$ boundaries. The relationship between unusual high $\mathrm{CO}_{2}$ levels in the atmosphere and mass-extinction events is commented. The origin of the greenhouse gases are attributed to: a) extensive outgassing of volatiles through of large volcanic events, or b) asteroid or cometary impact by bodies ranging up to $10 \mathrm{Km}$ in diameters, or c) marine and terrestrial organic production by living organisms.

Climatic changes have been detected in all the geological records, from Precambrian to Cenozoic. Tillites and varvites in Gondwana are features of Proterozoic and Paleozoic ice ages. The Mesozoic, on the other hand, had a global warm climate, exhibiting generally high level sea and low thermal variation between the poles and the equator. The Mesozoic continental geologic records in Gondwana are consequence of this arid climate, and the sedimentary rocks are mainly red-beds seguences or other related with arid/ semi-arid environments.

The relationship between the climate, geological records and paleogeographical aspects in the Mesozoic Central-South Gondwana are presented, focussing the NNE border of the Paraná and the Southern Sanfranciscana basins, which occur in the western part of Minas Gerais state. The Parecis Basin that occurs in Mato Grosso State is also mentioned.These basins show sequences of varied rock types -volcanic and sedimentary ones -, and exhibit ages ranging from early to late Cretaceous.

Other important paleogeographic feature studied occurs as a strip of intensely deformed Precambrian rocks forming a NW-SE tectonic arch, preserved as a succession of thrust slices. This is known as Alto do Paranaíba Arch or Alto do Paranaíba Anteclesis, (Ladeira et al. 1971, Grossi Sad et al 1971, respectively), a regional structure related with the emplacement of the Cretaceous Paraná and Sanfranciscana basins.
\end{abstract}

\section{INTRODUÇÃO}

Mudanças climáticas tem sido registradas ao longo praticamente de todas as Eras geológicas. Os registros vão desde o Pré-cambriano, em que, condições severas de exposição da crosta aos agentes intempéricos conferiam à mesma um caráter extremamente mutável. Exemplos conhecidos destes registros são as glaciações que atuaram no planeta desde o Proterozóico ao Paleozóico, as quais deixaram suas marcas nas terras do Gondwana Sul. Melhores registros são os decorrentes das variações climáticas do Cenozóico, que deixaram amplas impressões nas terras do Hemisfério Norte.

O Mesozóico, tema do presente trabalho, também deixou profundas impressões no Brasil. Como um todo, pode ser caracterizado por uma época de clima predominantemente quente, com níveis marinhos altos e pouca variação térmica entre o equador e os polos, se comparado com as condições atuais. O registro geológico continental observado em parte do Brasil corrobora esta suposição climática, apesar das dificuldades inerentes ao estudo destas rochas, ao contrário daquelas crono-correlatas presentes em nossas bacias costeiras. As dificuldades devem-se, dentre outros fatores, à restrita importância econômica destas rochas, ao seu registro fragmentário, ao geralmente alto grau de alteração intempérica além da ausência relativa de fósseis passíveis de serem correlacionados às colunas padrões estabelecidas.

Esse estudo descreve parte do registro geológico continental a partir do Mesozóico na porção centro-sul do Brasil, dentro de um contexto paleoclimático e paleogeográfico global, com ênfase nos processos e produtos desenvolvidos durante o Cretáceo.

$\mathrm{O}$ texto discute também as causas do aporte de $\mathrm{CO}_{2}$ na atmosfera terrestre, o qual, em conjunto com outros 

NNE DA BACIA DO PARANÁ E A PORÇÃO MERIDIONAL DA BACIA SANFRANCISCANA, NO OESTE DO ESTADO DE MINAS GERAIS

gases, como o $\mathrm{CH}_{4}, \mathrm{SO}_{2}$ e outros, comandam em grande parte as mudanças climáticas globais através do efeito estufa. As consequências são as interrupções na cadeia da vida, conforme registradas nos intervalos Permiano/Triássico (P/Tr) e Cretáceo/Terciário (K/T).

\section{CONSIDERAÇÕES ACERCA DA EVOLUÇÃO CLIMÁTICA}

Conforme sistematizado por Hsü (1992), a temperatura na superfície da Terra depende fundamentalmente de três fatores:

a) A energia solar emitida pelo sol (Luminosidade Solar);

b) A quantidade da energia solar refletida de volta ao espaço (Efeito Albedo);

c) A quantidade da radiação infravermelha emitida pela superfície do planeta e absorvida pela atmosfera terreste (Efeito Estufa).

Teorias mais recentes apontam os gases resultantes do efeito estufa com sendo o principal responsável pelas modificações climáticas em escala global que afetam a Terra. Deste modo, a principal causa das mudanças de temperaturas na superfície da Terra ao longo do tempo geológico tem sido, como consenso, a concentração anômala de $\mathrm{CO}_{2}$ e de outros gases na atmosfera terrestre, os quais absorvem e enviam de volta a radiação terrestre de longo comprimento de onda. Existem, entretanto, divergências com relação à origem desses gases.

Tradicionalmente, duas correntes de pensamento associam mudanças atmosféricas bruscas, em escala global, a dois fenômenos: vulcanismo em grande escala e impacto por um corpo extraterrestre. Alguns autores postulam que a principal causa do aumento brusco de $\mathrm{CO}_{2}$ e outros gases presentes na atmosfera do Mesozóico seria devida à atividade vulcânica, sendo que a quantidade de gases seria diretamente proporcional às suas intensidades (Frakes 1968, Budiko \& Ronov 1979, apud Hsü 1992, Officer \& Drake 1983, Morgan 1986, Rampino \& Stothers 1988, Dunkan \& Pyle 1988, Lavina 1992).

Neste sentido Morgan (1986) e Courtillot (1990), dentre outros, sugerem que o vulcanismo basáltico registrado tem sido sistematicamente relacionado às grandes extinções faunais, originando efeitos semelhantes aos descritos para impacto de bólido na superfície terrestre tais como incêndios em grandes proporções, tsunamis (ou maremotos), contaminação da atmosfera por cinzas ricas em elementos incomuns (p.e. platinóides) e a saturação atmosférica por gases, dentre eles o $\mathrm{CO}_{2}$, fenômenos precursores de um supostamente longo obscurecimento da atmosfera.

O evento vulcânico mais importante dessa Era foi o vulcanismo basáltico que afetou a plataforma siberiana, tendo fornecido idade ${ }^{40} \mathrm{Ar} / \mathrm{Ar}^{39}$ de cerca de 248 M.a. (Rene \& Basu 1991). Os derrames marcaram o final da era Paleozóica, delimitando a fronteira $\mathrm{P} / \mathrm{Tr}$, cobrindo uma área aproximada de 1,6 $\mathrm{x}$ $10^{6} \mathrm{Km}^{2}$, exibindo espessura máxima de $3700 \mathrm{~m} \mathrm{e}$ volume de $2,4 \times 10^{5} \mathrm{Km}^{3}$ de lavas. Um dado significativo foi a considerada curta duração do evento, de cerca de apenas 800.000-900.000 anos. Grandes quantidades de poeira e gases foram lançados à atmosfera. Clark et al. (1986) detectaram na China, um contínuo nível de argilas relacionadas com a precipitação de cinzas, possivelmente lançadas à atmosfera por um ou mais eventos vulcânicos explosivos ocorridos no limite $\mathrm{P} / \mathrm{Tr}$.

Com relação aos gases, os valores lançados à atmosfera devem também ter sido significativos, a julgar pelos dados comparativos formulados por Grout (1932) segundo os quais em termos médios lavas podem ter de 1 a $4 \%$ em volume de $\mathrm{H}_{2} \mathrm{O}$, quantidade equivalente a 70 "volumes de gás" por um volume de rocha. Shand (1969) mostrou que lavas do Kilauea possuem $4 \%$ em volume de gases, sendo a $\mathrm{H}_{2} \mathrm{O}$ o mais abundante, seguido por $\mathrm{CO}_{2}$ e $\mathrm{SO}_{2}$. Ocasionalmente entretanto, a quantidade de $\mathrm{CO}_{2}$ pode superar a de água (e.g. 36,18\% de $\mathrm{H} 2 \mathrm{O} ; 46,68 \%$ de $\mathrm{CO}_{2} ; 11,15 \%$ de $\mathrm{SO}_{2}$,etc).

Outra época tradicionalmente reconhecida pela ocorrência de intensa atividade vulcânica, igualmente relacionada com um grande evento de extincão em massa em escala global foi o final do Mesozóico. O vulcanismo foi representado pelos derrames basálticos do planalto de Deccan, no centro-oeste da Índia, o qual originalmente pode ter coberto uma área de cerca de $1,5 \times 10^{6} \mathrm{Km}^{2}$, alcançando espessuras máximas de 2000 m (Richards et al. 1989). Dados geocronológicos indicaram uma idade ${ }^{40} \mathrm{Ar} /{ }^{39} \mathrm{Ar}$, para o evento em $65-$ 69 M.a.,erupção que teria durado menos de 2 milhões de anos, constituíndo um evento geológico igualmente rápido. Novamente um expressivo vulcanismo de platô coincidiu com o segundo mais importante período de extinção faunal do Mesozóico, representado pela fronteira $\mathrm{K} / \mathrm{T}$.

A outra alternativa para as raras e pouco usuais mudanças ambientais globais detectadas ao longo de períodos geológicos é a causada pelo impacto de corpos extraterrestres na superfície do planeta, os quais poderiam ter causado as grandes extinções catastróficas descritas na literatura por Alvarez et al. (1980), Hsü \& McKenzie (1985), Hildebrandt et al. (1991), dentre outros. A questão tem sido considerada por muitos autores desde o trabalho pioneiro de Alvarez et al. (1980), relacionado à fronteira K/T. Hildebrand et al. (1991) relacionam a elevação climática neste intervalo ao impacto gerador da cratera de Chicxulub, na península de Yucatan, México, uma estrutura circular de cerca de $300 \mathrm{Km}$ de diâmetro. A colisão deu-se sobre uma plataforma carbonática com $3000 \mathrm{~m}$ de espessura e tais autores adotam a idéia manifestada por O'Keefe \& Arrens (1989 apud Hildebrand et al. 1991) e Pope et al. (1994 apud Ward et al. 1995) os quais postulam que a colisão poderia ter desencadeado as condições físico-químicas necessárias para dispersar grandes quantidades de $\mathrm{CO}_{2}$ e outros gases na atmosfera terrestre pela vaporização de carbonatos e sulfatos. A 
consequência teria sido um acréscimo de $10^{\circ} \mathrm{C}$ na temperatura média global por um período de $10^{4}$ a $10^{5}$ anos, responsável pela extinção faunal em massa ocorrida no período.

As conseqüências de um impacto de um meteoro com cerca de $10 \mathrm{~km}$ de diâmetro, por exemplo, teriam, segundo Grieve \& Robertson (1979), efeitos semelhantes à uma grande erupção vulcânica, porém seus efeitos seriam mais diversificados e catastróficos. Bourgeouis et al. (1988), Albertão et al. $(1992,1994)$ e Albertão \& Martins Jr.(1996), descreveram registros de tsunamis de grande porte, com cerca de 50-100 metros de altura. Lerbekmo \& Saint Louis (1986)e Lerbekmo et al. (1987) descreveram altos teores de iridium em litossomas associados à fronteira K/T e Albertão et al. (1994) no Brasil e Pitakpaivan et al. (1994) nos EUA mostraram minerais deformados por impacto de corpos extraterrestres ao longo da fronteira K/T. Feições similares foram descritas no Domo de Araguainha - uma estrutura circular com cerca de $40 \mathrm{Km}$ de diâmetro, impressa sobre sedimentos paleozóicos da Bacia do Paraná, nos limites entre os estados de Mato Grosso e Goiás -considerada como sendo formada por um impacto de meteorito durante o Cretáceo (Dietz et al. 1973, Theilen-Willige 1981, Crósta et al. 1981).

Um impacto na superfície do planeta por um corpo de grandes proporções, como aquele postulado para a fronteira $\mathrm{K} / \mathrm{T}$, teria levado à saturação da atmosfera por poeira e gases, à qual seguiria uma longa e persistente penumbra inibidora da fotossíntese, afetando a dieta dos hervíboros e em consequência a dos carnívoros (SalgadoLaboriaou, 1994).

O grande acervo de dados obtidos após o trabalho de Alvarez et al. (1980) levou McLaren (1983) a estabelecer critérios de probabilidades para relacionar impactos de bólidos extraterrestres com as grandes extinções faunais do Fanerozóico tais como: a) alta possibilidade $=a$ do limite Frasniano-Famenniano (Devoniano Superior) e da fronteira $\mathrm{C} / \mathrm{T}$; b) média possibilidade $=\mathrm{a}$ do Ordoviciano Superior e Triássico Superior e; c) pouca possiblidade $=$ Permiano Superior.

Dietz \& Holden (1970), Dietz (1972) e Medeiros (1992), adicionalmente indicam que o final do Paleozóico mostrou um contínuo deslocamento do Gondwana para o Norte, proporcionando uma gradual entrada dessas terras em àrea de influência equatorial. Deste modo procuram explicar um mecanismo de aquecimento global gradual no período. Lavina (1992) e Faccini (1989) adotam, como fatores associados à elevação climática, o espessamento crustal ocorrido no Gondwana à partir do final do Paleozóico, responsável pela expulsão das águas dos continentes, tão bem como à ação dos ventos atuando em mares continentais rasos entre latitudes $30^{\circ} \mathrm{N}$ e $30^{\circ} \mathrm{S}$, os quais teriam atuado na remoção da umidade dos continentes para o oceano.

Uma terceira teoria, mais recente, aponta para a possibilidade da Terra controlar sua própria temperatura pela ação dos seres vivos. A hipótese foi formulada por Lovelock (1988 apud Hsü 1992) e postula que o meio ambiente da Terra teria mudado com o advento da vida no planeta. A ação inconsciente dos organismos regularia o clima e os oceanos a um estado satisfatório para vida, mantendo a Terra em em equilíbrio interativo com os mundos orgânico e inorgânico. $\mathrm{O}$ conceito envolve a premissa de que todos os processos terrestres que atuam na atmosfera, hidrosfera, litosfera e biosfera estão relacionados no sentido de prover e sustentar a vida no planeta. Hsü (1992) quantifica os dados desta interação, abordando principalmente a paleooceanografia como fator principal na influência térmica global.

O fator primordial seria a ação dos organismos, indispensáveis nesta interação Hsü (1992). Neste sentido seria fundamental a atuação do $\mathrm{CO}_{2}$ nos oceanos, que ocorre na forma hidratada de $\mathrm{H}_{2} \mathrm{CO}_{3}$ e seus produtos dissociados, o íon $\mathrm{HCO}_{3}{ }^{-}$e o $\mathrm{CO}_{3}{ }^{-}$. Tais compostos interagem tanto no metabolismo dos microorganismos marinhos como na remoção do $\mathrm{CO}_{2}$ em circulação, através da precipitação de $\mathrm{CaCO}_{3}$. Estas idéias mostram que o aquecimento global pode estar, parcialmente ou não, relacionado com a atuação dos organismos e que a temperatura na superfície do planeta é ditada predominantemente pela vida. Hsü (1992) descreve que uma eventual supressão da vida na Terra poderia ocasionar o consumo de todo o $\mathrm{CO}_{2}$ atmosférico, originando um resfriamento global em apenas 10000 anos.

Tal fato seria devido ao balanço negativo de cinco unidades de carbono $\left(1\right.$ unidade $=10^{12}$ moles de $\mathrm{C}$ ) entre o suprimento de $\mathrm{CO}_{2}$ vulcânico elemental (11,7 unidades por ano) e aquele consumido pelo intemperismo terrestre (16,7 unidades por ano). Como contrapartida ao consumo de $\mathrm{CO}_{2}$ pela produção orgânica nos continentes, há a produção de $\mathrm{CO}_{2}$ pela evasão marinha e pela oxidação de outros gases atmosféricos como o $\mathrm{CO}$ e o $\mathrm{CH}_{4}$. $\mathrm{O}$ autor postula que o vulcanismo tem importância secundária ao aporte do $\mathrm{CO}_{2}$ à atmosfera, totalizando um pouco mais que $20 \%$ do total liberado pelos continentes e oceanos (Fig.1)

Neste sentido, parece existir consenso de que as modificações termais, pelo menos no Cretáceo foram primordialmente função da pressão de $\mathrm{CO}_{2}$ atmosférico, embora opiniões divirjam sobre suas causas (Frakes 1986). O efeito estufa que afetou este período tem sido interpretado como resultante da produção orgânica desenvolvida principalmente nos oceanos. Por exemplo, a remoção do $\mathrm{CO}_{2}$ em circulação pela precipitação do $\mathrm{CaCO}_{3}$ nos oceanos é um importante fator, sendo mensurado por Mackenzie (1990) em 16,6 unidades de carbono inorgânico por ano, atualmente. Plancton calcário depositado como lama carbonática absorve hoje 2/3 da perda, consumindo quase todo o gás vulcânico em circulação, sendo que o soterramento de todo o carbonato além do carbono orgânico em sedimentos alcançam 22,2 unidades de $\mathrm{C}$ por ano, totalizando quase o dobro do aporte de gases vulcânicos à atmosfera por ano.

Conforme Hsü (1992), ainda durante o Cretáceo, o 


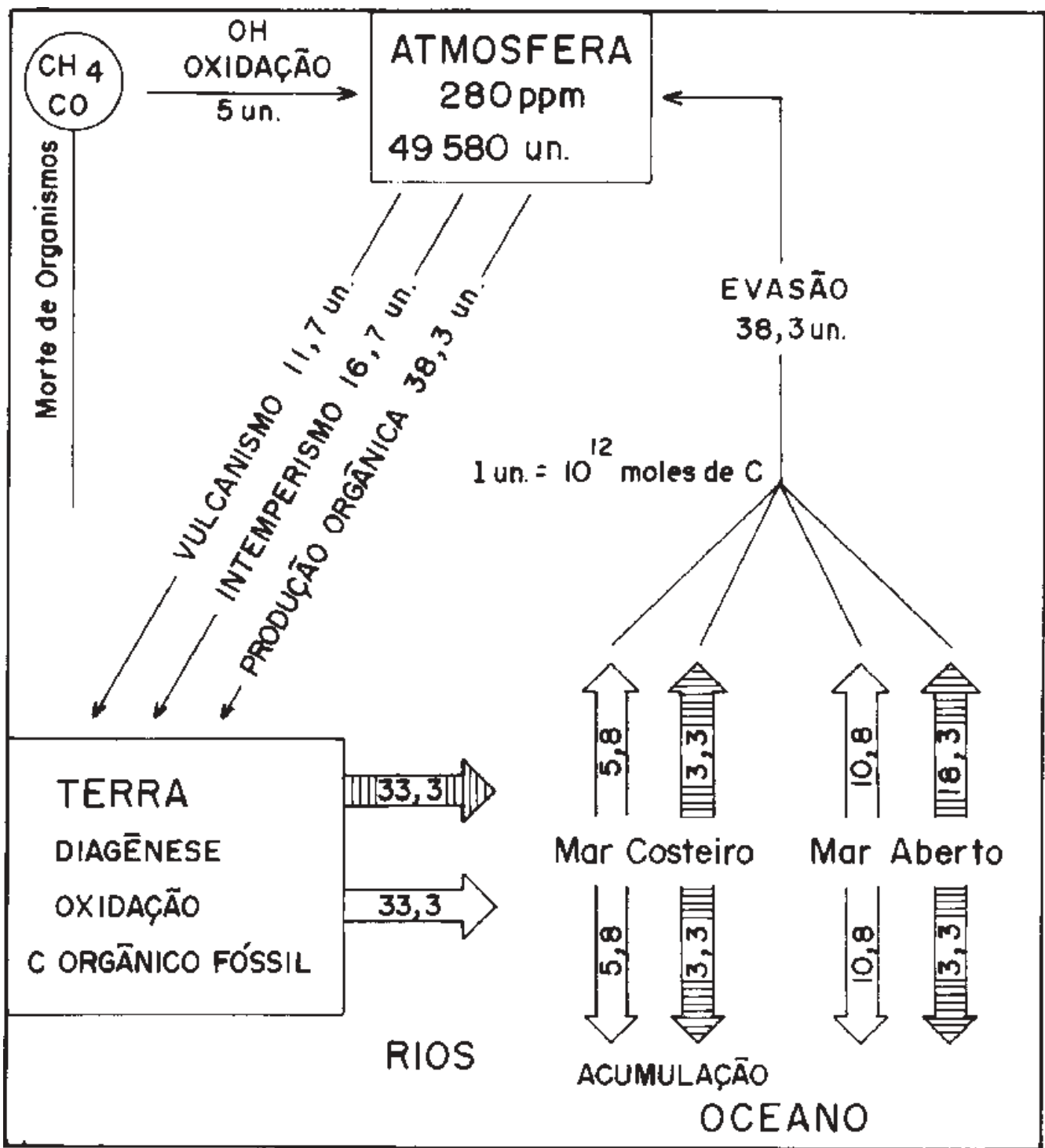

Figura 1: Modelo de Wollast \& MacKenzie para o ciclo geológico do CO ${ }_{2}$. Os fluxos são em unidades de $10^{12}$ moles de Clano. Fluxos de C orgânico são mostrados em setas com linhas paralelas e carbono inorgânico com setas claras (Segundo MacKenzie 1990).

Figure 1: Wollast \& MacKenzie's model of the long-term geological cicle of $\mathrm{CO}_{2}$. Fluxes in units of $10^{12}$ moles per year. Organic carbon fluxes shown in stripe and inorganic carbon in open arrows (After MacKenzie 1990).

advento das plantas angiospermas pode também ter contribuído para o resfriamento global nos últimos 100 milhões de anos. Volk (1989) sugere que o espalhamento dos ecossistemas angiosperma-decíduos poderia ter causado altas taxas de intemperismo. $\mathrm{O}$ incremento do fluxo de ions $\mathrm{Ca}^{++} \mathrm{e} \mathrm{Mg}^{++}$retirados de silicatos continentais contribuiria para o aumento do plancton calcário. A precipitação planctônica extrairia da atmosfera o dióxido de carbono.

Durante o Mesozóico o interior de Pangea assistiu ao advento do maior episódio de desertificação já conhecido, o qual perdurou até pelo menos o Cretáceo Médio. No Gondwana centro-sul, o conjunto sedimentar depositado sobre o substrato paleozóico da bacia do Paraná formou um dos maiores depósitos eólicos contínuos do planeta, sendo associado a um dos mais expressivos derrames de lavas já registrados.

\section{TRIÁSSICO}

\section{PALEOGEOGRAFIA E PALEOCLIMAS}

De acordo com Howell (1985) o período de 700 a 500 M.a. foi de grande fragmentação continental. O que se seguiu foi um período de amalgamento das terras ao longo dos antigos crátons ou núcleos continentais, constituindo os dois megacontinentes : Laurásia e Gondwana.

No Devoniano uma transgressão marinha proporcionaou a invasão da plataforma gondwânica (Torquato \& Cordani 1981). No final do Paleozóico, com as grande sinéclises preenchidas, a plataforma afrobrasileira emergiu, expulsando as águas oceânicas. Indicadores paleoclimáticos como tilitos e varvitos indicam a instalação de interlúdios frios em todo o 
Gondwana no final do Paleozóico. Nesta época de crescente continentalização da terras, o final do Permiano assistiu à presença de condições climáticas amenas no Gondwana. Expressivos corpos aquosos existentes no Sul do continente africano, os quais atingiam a América do sul, exerciam um efeito moderador do clima no Gondwana Central (Hulver et al. 1993) e Ziegler (1993).

Entretanto, evidências de clima seco começaram localmente a aparecer ainda no Permiano, conforme constatado pelas ocorrências de depósitos eólicos interdigitados com outros fluvio-deltáicos mostrados por Faccine (1989), indicando condições de aridez associados a períodos sazonais úmidos. Suzuki (1994 apud Suguio 1995) mostra que já no final do Carbonífero Superior os níveis de $\mathrm{CO}_{2}$ atmosférico começaram a crescer, atingindo o climax na fronteira $\mathrm{P} / \mathrm{Tr}$, época em seus valores alcançaram cerca de 5 vezes os valores atuais deste gás.

A paleogeografia do Triássico Inferior mostrava que o Pangea cobria cerca de um quarto da superfície do planeta, estendendo-se de polo a polo em uma estreita faixa que não ultrapassava $60^{\circ}$ de longitude, no sentido W-E, (Fig.2A).

O grupo de terras setentrionais da Laurasia separava-se das terras meridionais do Gondwana por uma estreita faixa descontínua de mar raso, localizada nas imediações do paralelo $45^{\circ}$ norte. O conjunto das terras então reunidas era limitada a oeste pelo grande oceano Panthalassa e a leste pelo mar de Tethys.

Conforme descrito por Faccini (1989),o posicionamento simétrico das terras com relação ao Equador proporcionou a geração de células de pressão formando ventos que se desenvolviam em vastas áreas continentais na altura de latitudes médias. Tais ventos coletavam pouca umidade dos oceanos adjacentes, situação que conferia ao Triássico um dos mais áridos paleoclimas de todo o passado geológico (Habicht 1979,Parrish \& Curtis 1982, Parrish et al. 1982).

Hallan (1985), em sua reconstrução paleogeográfica do Pangea propôs, para o segmento centro-ocidental do Gondwana -América do Sul e África-, o prolongamento de clima seco iniciando-se do Equador até às imediações do paralelo $60^{\circ} \mathrm{S}$. A sul, uma faixa de clima úmido sazonal alcança o paralelo $70^{\circ} \mathrm{S}$, precedendo uma zona peripolar úmida.

$\mathrm{O}$ advento do Triássico encontrou o interior das terras reunidas do Pangea submetida a um clima desértico, com o expressivo decréscimo do gelo polar e baixo gradiente de temperatura entre o Equador e os polos. A modificação das condições ambientais proporcionou a evolução de condições climáticas amenas com influência marinha marcante, para condições continentais cuja tendência teria sido a da criação de um amplo e complexo sistema desértico.

Como consequência do aquecimento global, a transição Paleozóico/ Mesozóico a cerca de 250 M.a. foi traumática para a vida no Planeta. A consequência mais dramática foi a extinção permo-triássica, a mais drástica da história da vida na Terra.

Em função do aquecimento a vida marinha foi devastada, com uma redução de $57 \%$ no número de famílias (Sepkoski 1986) e cerca de 96\% de extinção das espécies (Raup 1979). As formas terrestres foram também afetadas, com $77 \%$ de redução entre as famílias de tetrápodes (Maxwell \& Benton 1987).

Independente das causas -vulcanismo ou impacto extraterrestre- muitos dados relacionados ao evento permanecem obscuros ou conflitantes. Hsü \& McKenzie (1985) atribuíram pouca duração a seus efeitos mais imediatos, em cerca de 1000 anos baseados na rápida variação do gradiente dos valores de isótopos de carbono detectados em rochas que ocorrem ao longo das fronteiras P/Tr e K/T. De modo diverso, Magaritz et al.(1988) descreveram a modificação gradual no conteúdo em ${ }^{13} \mathrm{C}$ em carbonatos marinhos do permotriássico dos Alpes meridionais na Itália e Áustria. A mudança gradual do ${ }^{13} \mathrm{C}$ ao longo da fronteira $\mathrm{P} / \mathrm{Tr}$ corresponde a 20-30 m de sedimentação carbonática, equivalente ao intervalo de 0.1-2 milhões de anos (Wilson 1975, Maxwell 1989).

De acordo com McLaren (1983), existem poucas evidências que sustentem a existência de um impacto extraterrestre na superfície do planeta, no final do Paleozóico. A alternativa seria ditada pelo vulcanismo síncrono com o intervalo $\mathrm{P} / \mathrm{Tr}$, representado pelo expressivo derrame basáltico que afetou a Sibéria, o qual poderia ter liberado o excesso de $\mathrm{CO}_{2}$ para a atmosfera, necessário a um aquecimento global. O papel da atuação reguladora do clima por parte dos organismos nesta época, deve ter sido extremamente minimizado,segundo Hsü (1992). Sabe-se que os organismos de então não poderiam ainda atuar como agentes modificadores do clima, pela ausência das plantas florescentes nos continentes e pouca expressão dos organismos planctônicos calcários nos oceanos, formas de vida que não constituíam frações significantes da biomassa até o Cretáceo. A não fixação do carbono por organismos contribuiu para o prevalecimento de condições gerais desérticas (Hsü 1992).

\section{REGISTROS GEOLÓGICOS NO BRASIL}

A evolução climática a partir do Permiano mostra condições crescentes de aridez no Gondwana Sul, sendo que a sedimentação mesozóica mais antiga do País encontra-se no Extremo Sul. O litossoma triássico é representado pelo Grupo Rosário do Sul constituído da base para o topo, segundo Andreis et al. (1980, apud Faccini 1989), pelas formações Caturrita e Santa Maria. São sedimentos de origem flúvio-lacustre, os quais exibem os mais ricos e conhecidos jazigos fossilíferos do Triássico meridional do País. São sedimentos predominantemente arenosos, que preencheram parcialmente a depressão periférica do Rio Grande do Sul, exibindo fósseis de répteis de grande porte como os das ordens Rhynchocephalia, Saurischia, Cynodontia, Pseurosuchia e Anomodontia, descritos 


\section{A - Triássico inferior}

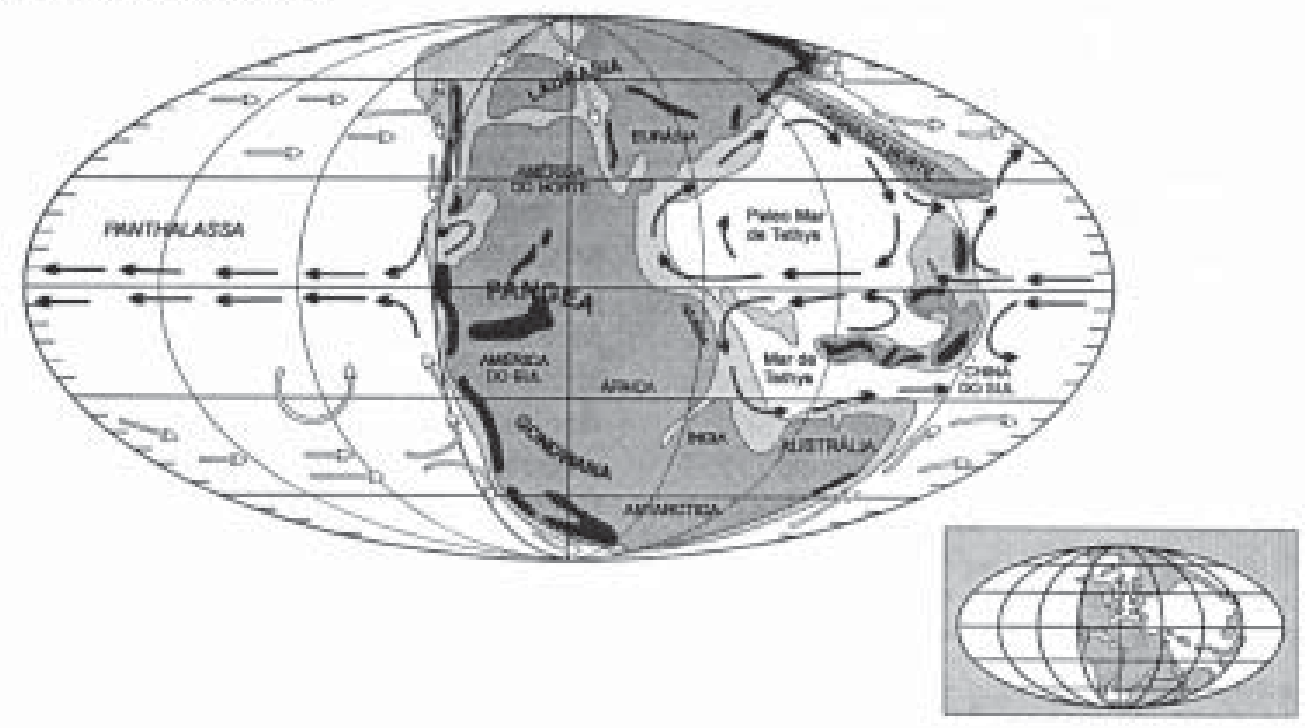

B - Jurássico superior

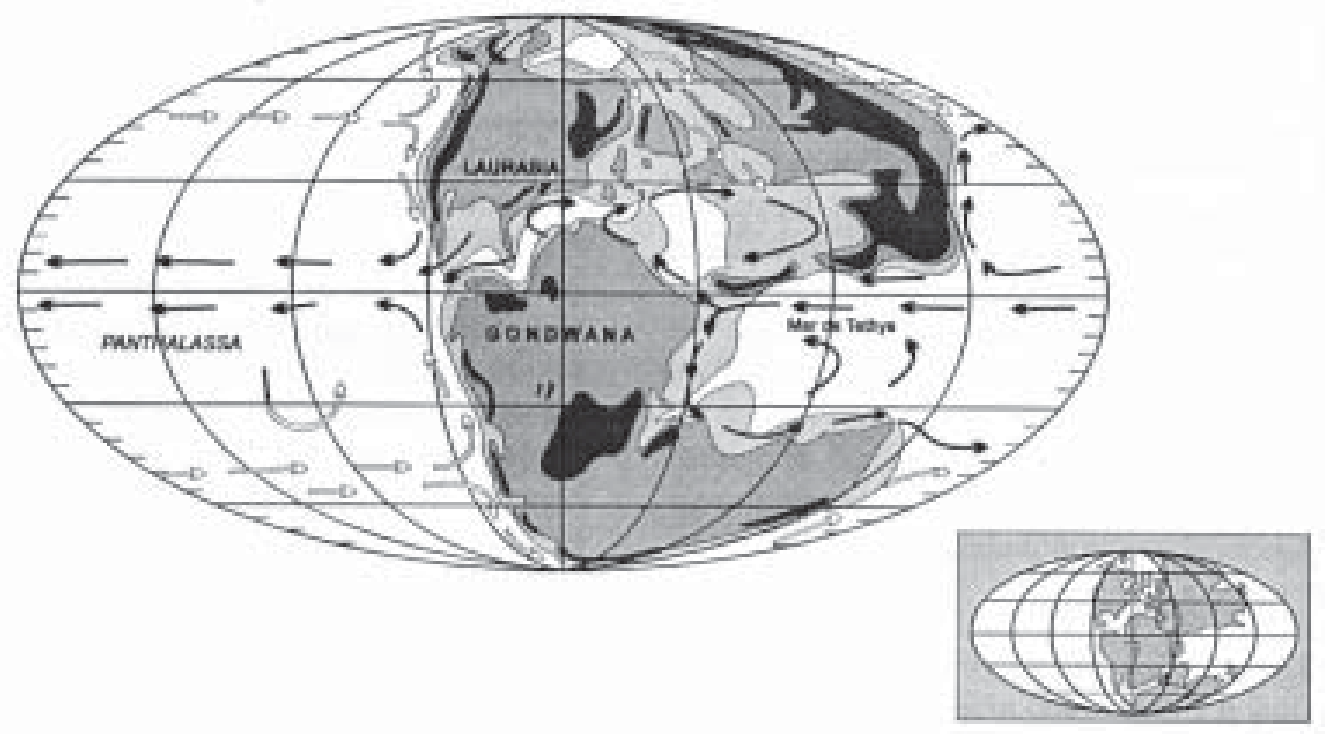

C - Cretáceo superior

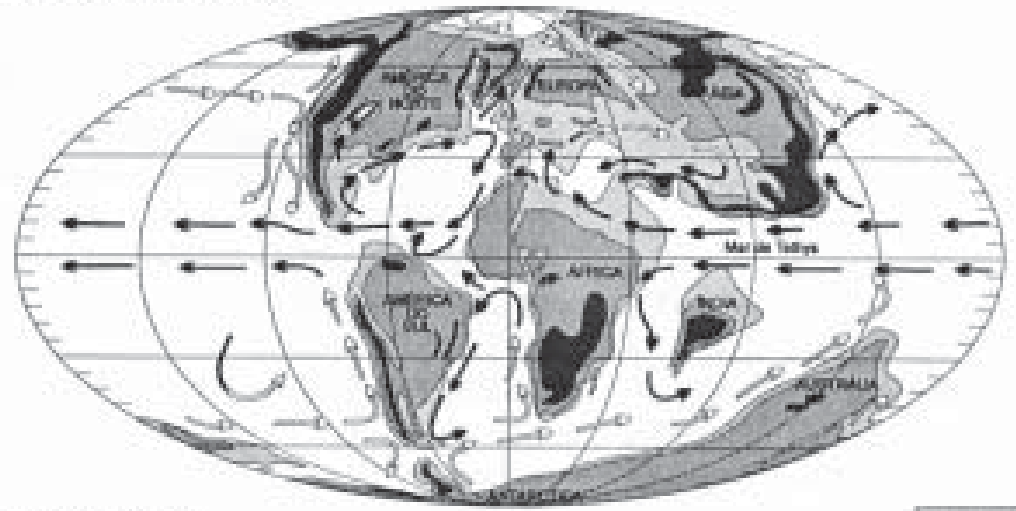

[D] Corran a doub

$\rightarrow$ Cormas a douquen

Movieves

Terse llabas

Marse nase

Beves mesmes gokinter

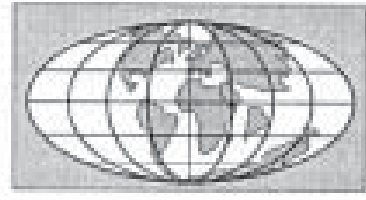


originalmente por Huene (1942) e posteriormente por outros autores como Barberena (1977) e Schultz e Azevedo (1990). Abundande ocorrência da flora Dicroidium, de importante significado geocronológico, foi descrita por Bertoluzzi (1974 apud Faccini 1989). O próprio Faccini (1989) analisa esta sequência continental sob o ponto de vista deposicional.

Condições mais amenas no início do Triássico, onde a fauna era dominada por Therapsida, evoluiram rapidamente para uma crescente desertificação. Exemplos conhecidos são vários, dentre os quais podese citar as restrições faunísticas da Formação Santa Maria, tendo sido observado o decréscimo na população reptiliana de Dycinodon e a predominância de formas mais adaptadas às novas condições ambientais mais severas, onde predominavam répteis Rhynchocephalia da família rincossaurídeos (Peruzzo \& Schultz 1992). Segundo estes autores, após a extinção dos rincossaurideos, paleoambientes mais amenos permitiram a volta dos Dycinodon, indicando leves oscilações no regime climático do Triássico que permitiu a provavelmente restrita preservação de nichos adequados à vida local. Holtz (1972) indicou, com base em evidências faciológicas, períodos de considerável umidade, relacionados a existência de corpos d'água não perenes que sustentavam de modo episódico a vida local. Entretanto, em termos globais, evidência do amplo espalhamento geográfico das condições climáticas áridas no período foram mostradas por Lavina (1992) que menciona a ocorrência de flora e fauna reptiliana em paleolatitudes de $85^{\circ} \mathrm{S}$ no início do Triássico da Antártica.

Pinto e Ornelas (1974), baseados no estudo de insetos posicionaram a Formação Santa Maria no topo do Triássico Médio - base do Triássico Superior
(Ladiniano Superior -Carniano Inferior)- sendo cronocorrelatas às formações Ischigualasto e Molteno da Argentina e África respectivamente.

Evidências mais marcantes da desertificação em grande escala observada no Triássico são demonstradas pela Formação Pirambóia, depositada sobre o substrato permiano da Bacia do Paraná. Soares \& Assine (1992) indicaram a existência de atividade tectônica pós-permiana, gerando uma discordância angular entre os dois pacotes, identificadas nos flancos sudeste, leste e norte da Bacia do Paraná.

A Formação Pirambóia possui ocorrências verificadas nos estados do Rio Grande do Sul, Paraná e São Paulo, estando, segundo Soares \& Assine (1992), aparentemente ausente em Santa Catarina, local em que o Arenito Botucatu, cretácico, sobrepõese diretamente aos sedimentos permianos da Formação Rio do Rasto. Autores como Gamermann (1973), Soares (1975), Fúlfaro (1980) e Soares \& Assine (1992) interpretaram a Formação Pirambóia como uma variação faciológica do Grupo Rosário do Sul.

A Formação Pirambóia foi inicialmente reconhecida como Triássica por Almeida (1954), baseada na fáunula de ostracódes presentes em folhelhos lacustres associados aos depósitos eólicos, estes mais característicos dessa formação. Esta idade foi confirmada e estabelecida como sendo tatarianaeoscythiana por Ricominni et al. (1984) e Lavina (1992), sendo que seus litossomas mostram condições de crescente aridez a partir do Triássico Inferior. A formação é constituida por sedimentos areno-siltosos com intercalações de folhelhos, totalizando cerca de 400 metros de espessura na bacia do Rio Tietê no Estado de São Paulo (Soares 1973 apud Franzinelli 1973), alcançando ainda cerca de 655 metros em Alegrete no Estado do Rio Grande do Sul (Lavina \& Faccini 1992).

Figura 2: Reconstituição paleogeográfica e paleoceanográfica do Mesozóico mostrando a distribuição das elevações, bacias e padrões de circulação das correntes marinhas. A configuração dos atuais continentes são vistas no detalhe. (A) Triássico Inferior mostrando Pangea como uma faixa alongada no sentido $\mathrm{N}-\mathrm{S}$, aproximadamente simétrica com relação ao equador e que cobria cerca de 25\% da superficie terrestre; (B) Jurássico Superior mostrando a ligação restrita de Tethys com Panthalassa e a consolidação da Plataforma da China expandindo-se para leste. Ao Sul nota-se o incipiente rifteamento na borda leste do Gondwana com a formação de montanhas no interior do continente. As bordas ocidentais da América do Sul e do Norte colidiram-se com a margem oriental da Placa do Pacifico e suas microplacas; (C) O Cretáceo Superior mostra os atuais continentes austrais ensejando a abertura do Atlântico Norte entre a América do Norte e Eurásia. As terras austrais mostram as regiões dos atuais continentes já individualizadas com exceção da Austrália e Antarctica, ainda conectadas. Nota-se a já efetiva circulação marinha no Atlântico Sul alcançando Tethys na área do futuro Golfo do México.(Modificado de Scotese, C.R., IN: The New Encyclopaedia Britannica, 1993, 15 a edição, fig. 37, v.19, p.830-841).

Figure 2: Mesozoic Paleogeography and Paleoceanography showing the distribution of the land masses, mountainous regions, shallow seas and deep ocean basins, including the reconstruction of the warm and cold ocean currents. The presentday coast lines and tectonic boundaries of the configured continents are showed in the insets. (A) Early Triassic showing stretched Pangaea from pole to pole in a narrow belt and consisted of a group of northern continents, Laurasia, and a group of southern continents, Gondwana; (B) Late Jurassic reconstruction showing the Thetyan geossinclyne between Laurasia and Gondwana. Active plate collisions took place around the western margin of the Pacific Plate. The western margins of North America and South America collided with the Pacific Plate in this region. Note the initial fragmentation of the eastern margin of Gondwana;(C) Early in the Cretaceous, North America and South America were separated sufficienttly for the marine connection between the Tethys and Pacific to deepen substantially. By the end of the Cretaceous, the present-day continents were separate entities except for Australia, which was still joined to Antarctica Also,note the well developed marine currents between Tethys and South Atlantic (Modified from Scotese,C.R., IN. The New Encyclopaedia Britannica, 1993, 15 a edição, fig. 37, v.19, p.830-841). 
A Formação Pirambóia resulta predominantemente de deposição eólica. Entretanto, vários autores identificaram fácies fluviais e lacustres, indicando uma natural associação aquosa em um amplo sistema desértico. Por exemplo, Franzinelli (1973) indicou deposição fluvial com pequenos depósitos lacustres associados. Almeida (1954) admitiu a deposição por rios de pequeno porte que se desenvolviam sobre um extenso pediplano sujeito a um clima relativamente úmido demonstrado pela presença de grânulos limoníticos em sua base, porém com prolongados períodos secos. Ricomini et al. (1984) e Cottas et al. (1986) atribuem ao Pirambóia também uma origem essencialmente fluvial. Caetano-Chang et al. (1992) e Lavina \& Faccini (1992) descrevem entretanto fácies essencialmente eólicos para a Formação Pirambóia na região de São Pedro no Estado de São Paulo e Alegrete no Estado do Rio Grande do Sul. Almeida e Barbosa (1953) já tinham demonstrado essa característica deposicional múltipla do Pirambóia, quando admitiram que tais depósitos representaram o reflexo de uma variação climática no bojo de um amplo regime desértico, gradando de condições mais úmidas na base para desértica no topo (Tabela 1).

O sistema eólico do topo da Formação Pirambóia evoluiu para o desenvolvimento de depósitos arenoargilosos flúvio-lacustres, em regime semi-árido ou árido periférico de caráter endorréico, reunidos sob a designação de Arenito Santana (Almeida e Barbosa 1952 apud Almeida 1954), admitida posteriormente como um facies da Formação Pirambóia. Ela representaria o entulhamento dos baixos interdunas por detritos transportados por água, de maneira semelhante aos atuais Oueds saarianos, exibindo ainda, associados, pavimentos deflacionários com ventifactos de quartzo e quartzito trabalhados in situ pelo vento. Localmente observam-se ritmitos com fáunula de Conchostraca indicando uma suficiente perenidade para os corpos lacustres. Essa evolução mostra uma nova oscilação dentro de um regime quente, de árido para um regime semi-árido mais ameno. Seu topo mostra entretanto, alternâncias com sedimentos eólicos indicando a retomada de condições desérticas.

\section{JURÁSSICO}

\section{PALEOGEOGRAFIA, PALEOCLIMAS E REGISTROS GEOLÓGICOS}

No início do Jurássico perduravam as mesmas condições de extensiva continentalidade registradas no final do Triássico. O Pangea mantinha-se íntegro levando à formação de geossinclínios ao longo de praticamente todas as margens continentais. O nível marinho foi relativamente alto (McLaren, 1983), com

\begin{tabular}{|c|c|c|c|c|}
\hline Autor/ano & Idade & Ambiente & Local & Publicação \\
\hline Washburne,1930. & - & fluvial & São Paulo & $\begin{array}{l}\text { Bol.Co.Geog.Geol., } \\
\text { SP,(22):1-282 }\end{array}$ \\
\hline $\begin{array}{c}\text { Almeida e Barbosa } \\
1953 .\end{array}$ & - & fluvial & Piracicaba e Rio Claro, SP & Bol.143, DNPM., 21p. \\
\hline Franzinelli, 1973. & - & predominantemente fluvial & $\begin{array}{c}\text { Entre SW dos rios } \\
\text { Paranapanema e Tietê e } \\
\text { NE do rio Piracicaba (SP) }\end{array}$ & 27o.C.B.G.,p.229-236 \\
\hline Almeida,1954. & $\begin{array}{l}\text { Triássica (fáunula de } \\
\text { conchostráceos) }\end{array}$ & $\begin{array}{l}\text { lacustre no topo; } \\
\text { fluvial na base }\end{array}$ & SP-PR-SC & Bol 86 DNPM, 21 p. \\
\hline Soares, 1975. & - & fluvial & São Paulo & $\begin{array}{l}\text { Rev.Bras.Geoc. } \\
\text { (5)4:229-51 }\end{array}$ \\
\hline $\begin{array}{c}\text { Thomaz } 1976 \text { in Leonardi } \\
1980 .\end{array}$ & $\begin{array}{l}\text { Jurássica (Aalenian } \\
\text { Sup.-175 M.a.)Rb/Sr }\end{array}$ & fluvial & Araraquara, SP & An.Ac.br.Ci.., (52)3:559-67 \\
\hline Ricomini et al 1984. & Permo-Triássica & fluvial & Serra do Cadeado,PR & 28o.C.B.G.., p.754-63 \\
\hline Cotas et al.1986. & - & fluvial & $\begin{array}{c}\text { NE de SP, Guarapuava e } \\
\text { Ponta Grossa, PR }\end{array}$ & 34o.C.B.G., p.191-205 \\
\hline Caetano-Chang et al. 1991. & - & eólico, fluvial subordinado & São Pedro, SP & $\begin{array}{l}\text { 2o.Simp.Geol. Sud.,SP: } \\
53-58\end{array}$ \\
\hline $\begin{array}{c}\text { Lavina e Faccini } 1992, \\
\text { Lavina } 1993 .\end{array}$ & $\begin{array}{c}\text { Permo-Triássica } \\
\text { (Tatariano-Eosythiano). } \\
\text { Ocorrências de tetrápodes } \\
\text { associados. Fácies das } \\
\text { Fms. Rio do Rasto (RS) e } \\
\text { Sanga do Cabral (base). }\end{array}$ & $\begin{array}{l}\text { eólico, com flúvio-lacustre } \\
\text { subordinado. }\end{array}$ & $\begin{array}{l}\text { Depressão situada a W e } \\
\text { NW do Escudo do RGS }\end{array}$ & $\begin{array}{c}\text { Acta Geol.Leop. no.38, } \\
\text { 16:179-93 }\end{array}$ \\
\hline $\begin{array}{c}\text { Caetano-Chang e Wu } \\
1994 .\end{array}$ & Triássica & eólico, fluvial subordinado & São Pedro, SP & Geociências 13(2):371-85 \\
\hline
\end{tabular}

Tabela 1: Evolução dos conhecimentos gerais relativos à Formação Pirambóia, de idade Triássica, que ocorre na Bacia do Paraná.

Table 1: General data about the Triassic Pirambóia Formation, Paraná Basin. 
temperaturas relativamente uniformes ao longo de praticamente todas as latitudes. No decorrer do período, a época foi caracterizada pela intensificação dos fenômenos geológicos como a ruptura do Pangea e a abertura das bacias oceânicas.

$\mathrm{Na}$ costa oeste do Gondwana, ao longo da précordilheira andina, bacias de arcos magmáticos permaneceram ativas até pelo menos o Cretáceo Inferior, época em que o processo foi invertido pela tectônica regional (França et al. 1995). Grandes acumulações de lavas andesíticas com intercalações de calcários e calco-arenitos ocorreram ao norte do Chile. Para leste, no domínio das bacias de arco interno, houve o preenchimento com calcário, arenito e folhelho. Depósitos desta idade são importantes economicamente, porque constituem as mais expressivas acumulações de hidrocarbonetos da margem oeste do continente sul americano.

No Jurássico Médio - Superior, a ainda incipiente conecção oceânica que evoluiria no Cretáceo, formava um braço aquoso que limitava o Gondwana a norte e Laurásia a sul certamente contribuindo para o aporte de alguma umidade em partes continentais.

Grande variedade faunística instalou-se nos continentes com os répteis dominando praticamente todos os ambientes continentais. O período caracterizou-se também pela multiplicidade de organismos unicelulares assim como o com extenso espalhamento de vegetação tipo savana com florestas localisadas. A ausência de glaciações nas imediações das regiões polares indica que, globalmente, o clima era predominantemente quente, porém com nichos de umidade suficiente para suportar a explosão de vida no período.

No Gondwana, adentrando o continente à partir do geossinclíneo andino, acumulações típicas de clima árido como evaporitos ocorrem no Acre na Formação Juruá-Mirin. Também ocorrem na porção basal da Formação Aliança, Bacia do Recôncavo, atestando a continuidade do clima desértico em amplas porções desta parte do Gondwana no Jurássico Inferior. Posteriormente a instalação de regimes mais úmidos na região desta última bacia pode ser verificada pela instalação de planícies de inundação associada a lagos, formando o sistema desposicional "rift" que preencheu as bacias da área do Recôncavo.

No interior do continente, a maior parte do Jurássico no Gondwana Sul transcorreu com baixa taxa de sedimentação. Uma ampla e estável superfície de denudação, estável desde o final do Paleozóico, suportava prolongados processos erosionais. A estabilidade tectônica impedia a geração de embaciamentos e a ausência de regimes climáticos úmidos em termos regionais impedia a instalação de sistemas aquosos no interior do continente.

O Jurássico Inferior foi marcado por uma extinção faunal de grande magnitude, verificado nos estágios Pliensbachiano-Toarciano (Little \& Benton 1995). Embora o fenômeno tenha sido melhor registrado no
Noroeste europeu, o mesmo foi também observado nos domínios tethyanos e em oceanos austrais.

Montes-Lauar et al. (1994) descreveram parte do vulcanismo basáltico relacionado à reativação tectonomagmática que afetou a plataforma sul-americana desde o permo-triássico. Dois eventos, constituídos por basaltos toléíticos, forneceram idade $\mathrm{Ar}^{40} / \mathrm{Ar}^{39}$ de cerca de 197 M.a. (estágios Sinemuriano-Pliensbachiano do Jurássico Inferior). O primeiro representa a Formação Tapirapuã, substrato da Bacia Cretácica dos Parecis em Mato Grosso (Petri \& Fulfaro 1981), a qual forma um corpo alongado no sentido NE-SW com espessura máxima de 315 metros. O segundo corpo magmático refere-se à Formação Anari que ocorre no sudeste de Rondônia, posicionada no sentido W-E e com espessura máxima de 85 metros.

Manifestações magmáticas do mesmo período também foram detectadas cortanto rochas proterozóicas do Supergrupo Espinhaço, na parte centro-leste de Minas Gerais, em forma de diques máficos orientados nos sentidos NW-SE e W-E. Mostraram segundo Dossin et al. (1995) idades $\mathrm{K}^{40} / \mathrm{Ar}^{40}$ entre 192 a 171 milhões de anos, posicionando-se do Pliensbachiano Médio ao Bajociano Médio, Jurássico Médio Inferior à base do Jurássico Superior.

Tais manifestações magmáticas no Jurássico cortaram extensa parte da plataforma brasileira. Apresentam-se, do Espinhaço, porção leste do Estado de Minas Gerais até Rondônia, numa lineação orientada aproximadamente na direção SE-NW, mostrando ainda magmatismo mais antigo no sentido NW. Se a datação de Dossin et al (1995) não foi influenciada pela perda de Ar -portanto indicando uma idade mínima-, o cenário pode refletir possivelmente um movimento para noroeste da placa gondwânica sobre uma fonte magmática, no Jurássico Inferior a Médio.

Um dos mais extensos depósitos mesozóicos da parte ora estudada do Gondwana é representado pela Formação Botucatu do Grupo São Bento, que ocorre ao longo de toda a Bacia do Paraná e imediações. Apesar de Leonardi \& Oliveira (1990), baseados na comparação de estruturas de associações de ichnofaunas de São Paulo e da Argentina, atribuirem idade entre o Jurássico Inferior a Médio para a Formação Botucatú. Entretanto, como será mostrado adiante esses depósitos originaram-se mais provavemente no Jurássico Superior, tendo desenvolvido-se mais plenamente no Cretáceo Inferior.

Outras evidências litológicas de clima árido no final do Jurássico podem ser encontrados em locais tão distantes como no Nordeste, representadas pela Formação Pastos Bons (Aguiar 1971, Mesner \& Wooldridge, 1964) e Formação Aliança da Bacia do Recôncavo (Medeiros 1992).

No final do Jurássico o Gondwana iniciou o processo de fragmentação, seguindo, no Cretáceo Inferior, pelos derrames de basaltos toleíiticos superpostos aos arenitos Botucatu, extravasados ao longo de grandes estruturas extensionais intracontinentais.

No Jurássico Superior a configuração dos continentes mostra a Laurasia e o Gondwana separados, limitados pelo prolongamento de Tethys para oeste até 
Panthalassa (Fig.2B).

\section{CRETÁCEO}

\section{PALEOGEOGRAFIA E PALEOCLIMA}

Com cerca de 78,5 milhões de anos de duração (145 a 66.5 milhões de anos, de acordo com Harland et al. 1989), o Cretáceo constituiu o mais longo período do Mesozóico. Representa, dentre outros aspectos, a evolução de um mundo extremamente diferente do atual (no que diz respeito ao relevo, paleogeografia, clima, vulcanismo, circulação oceânica e megaformas de vida), para o mundo cenozóico, com características similares ao mundo atual.

Conforme descrito, o interior do Pangea durante o Triássico e Jurássico era um grande deserto. O Cretáceo Inferior foi também foi um período quente. Erosão terrestre e ausência significativa de vegetais podem ter mantido livres grandes quantidades de carbono fóssil em circulação, fazendo com que o efeito estufa tenha prevalecido até pelo menos o Cretáceo Médio, onde as condições climáticas se inverteram (Fig.3)
De acordo com Weissert \& Lini (1991), baseados na correlação entre dados paleoclimáticos e isotópicos, a já significativa produção de plancton aliada ao alto grau de preservação de carbono marinho orgânico pode ter levado à interlúdios glaciais após o Cretáceo Médio. De fato sabe-se que uma das características ambientais do Cretáceo foi a grande geração e fixação de matéria orgânica, depositada no mar equatorial de Tethys, hoje encontrada como hidrocarbonetos no Golfo do México, Venezuela, Líbia e Golfo Pérsico. Corroborando tais dados, Lavina (1992) descreve o registro de répteis e material florístico no Alaska e Groelândia em paleolatitudes superiores a $70^{\circ} \mathrm{N}$, com os polos exibindo condições climáticas temperadas. São conhecidos depósitos de evaporitos depositados principalmente entre $10^{\circ}$ a $30^{\circ}$ de latitude, o que pode confirmar as condições desérticas subtropicais, a par da objeção de vários autores associando tais depósitos mais com restrição de bacias do que com efeitos climáticos. Evidências florais mostram que condições tropicais a subtropicais chegaram a prelavecer em latitudes de até $45^{\circ}$, com condições temperadas imperando nos polos. Tais condições proporcionaram nível do mar alto

CURVA DE TEMPERATURA PARA BAIXAS LATITUDES

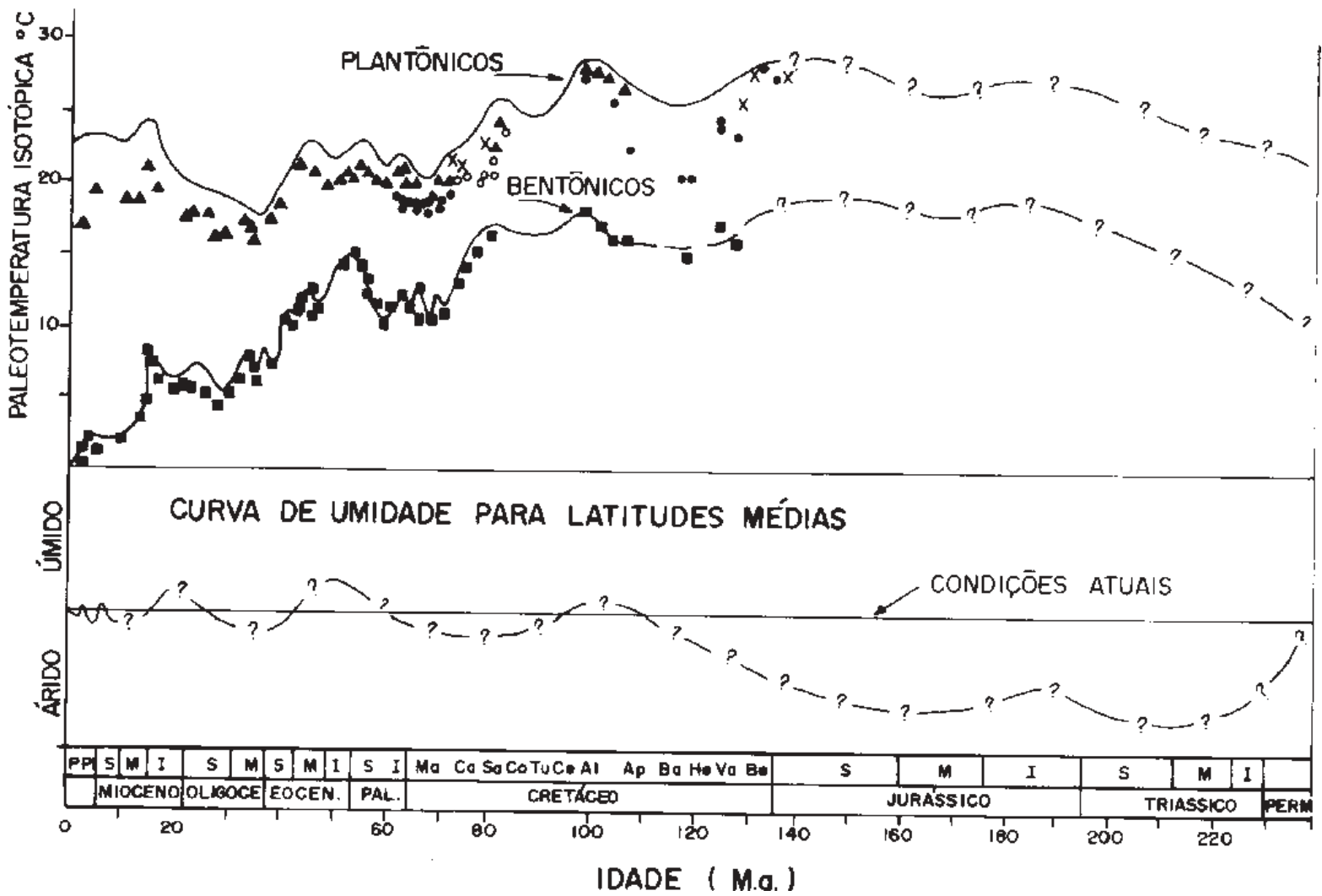

Figura 3: História climática do Mesozóico e Cenozóico, mostranto a paleotemperatura isotópica em baixas latitudes e curvas de temperatura em latitudes médias. Os dados confirmam o clima quente no Triássico, Jurássico e Cretáceo Inferior, quando iniciaram-se os pulsos frios relacionados com interlúdios glaciais que se prolongaram até o Cenozóico. (Segundo Frakes 1986).

Figure 3: Mesozoic and Cenozoic climate history showing composite temperature curve for low latitude and mid latitude humidity curve. Data show that the climate was warming up in the Triassic, Jurassic and Early Cretaceous time, when occured cooling episodes. (After Frakes 1986) 
durante quase todo o período.

O início do Cretáceo mostra uma configuração das terras emersas constituída essencialmente pelos dois continentes, Laurasia e Gondwana, separados pelo mar equatorial de Tethys. Águas do Ártico conectavam o Tethys através da América do Norte e da Rússia e águas do incipiente Atlântico Sul também alcançavam Tethys através das atuais Nigéria, Líbia e Tchad, fazendo com que, no período de nível marinho máximo, apenas $18 \%$ das terras se mantivessem emersas, ao contrário dos $28 \%$ atuais.

O cenário paleogeográfico do Cretáceo Superior mostra que a América do Norte iniciou sua separação do continente da Eurasia, enquanto a América do Sul já tinha consolidado sua separação do continente africano, do qual a Índia, a Austrália e a Antártica tinham se separado. Já se instalaram, no Atlântico Sul, células de circulação marinha que se conectavam com o já aberto Golfo do México. O final do Cretáceo encontra a Índia movimentando-se para norte no Oceano Índico, em direção à Ásia e a Austrália ainda conectadas à Antártica. A Fig.2C mostra a geometria das terras no Maastrichiano à cerca de 70,5 milhões de anos.

Dados radiométricos da margem atlântica da América do Sul revelaram a ausência de rochas magmáticas entre o intervalo de 100 a 120 M.a. Com base neses dados, Mizuzaki et al. (1996) sugeriram que a separação estrutural entre os continentes sulamericano e africano foi mais recente do que 100 M.a., com a efetiva separação por volta de 90 M.a. (Cenomaniano-Turoniano).

Outros dados sobre a ligação entre a América do Sul e África, com importante implicação paleogeográfica sobre a gênese do Atlântico Sul foram reportados por Dimas-Brito (1995 a, b), com base na similaridade entre organismos zoo e fito-planctônicos presentes em rochas carbonáticas do Golfo do México, Europa, Norte da África e Ásia, com aqueles presentes ao longo da costa norte do Atlântico Sul na margem brasileira. $\mathrm{O}$ autor indicou uma ligação entre as duas massas aquosas, considerando esta parte do Atlântico um prolongamento, para sul, do oceano tethyano. O limite sul deste oceano teria sido a região do Platô de São Paulo-Walvis que constituía, no Aptiano-Albiano (cerca de 112 M.a.) uma ligação entre a América do Sul e África. A ligação foi efetiva, de tal modo que as águas situadas ao sul deste platô não exibem a biota pelágica tethyana presente ao norte.

Os evaporitos aptianos que ocorrem ao longo da costa a norte do País também teriam sido depositados por águas provenientes do Norte, ponto de vista que diverge da idéia clássica que considera a primitiva porção setentrional do Atlântico Sul com uma massa de águas fria ou temperada, proveniente de partes austrais. Com a elevação marinha do final do Albiano, este braço sulino de Tethys teve sua individualidade perdida.

Calvo \& Salgado (1996) descrevem também dados relativos à esta conecção entre a América do Sul e
África, estendendo-a entretanto, desde o Albiano até o Cenomaniano (112-90 M.a.). Os autores descrevem jazigos fossilíferos compartilhando sauropodes Rebbachisaurus tessonei (Calvo \& Salgado, 1991 no prelo) do Albiano-Cenomaniano da Argentina com Rebbachisaurus garasbae (Lavocad, 1954) do AptianoAlbiano de Marrocos, além de titanossauros Andesaurus delgadoi (Calvo \& Bonparte, 1991) do Albiano-Cenomaniano da Argentina com Malawisaurus dixeyi (Jacobs et al. 1993) do Cretáceo Inferior de Malawi.

Decréscimo na temperatura global foi detectado a partir do Cretáceo Médio, porém uma abrupta parada na tendência ao aquecimento no final do período, levou muitos autores a postular a ocorrência de um fenômeno extraordinário, o qual coincidiu com o intervalo $\mathrm{K} / \mathrm{T}$. As consequências decorrentes do evento - vulcanismo ou impacto - foram catastróficas para o meio-ambiente, com (a) obscurecimento da atmosfera por poeira que se elevou até a estratosfera, durante meses ou anos (Alvarez et al. 1980), (b) subseqüentemente, instalouse uma idade de gelo, com a temperatura caindo $-40^{\circ} \mathrm{C}$. Dados isotópicos de oxigênio mostraram evidências de oceanos frios em sedimentos depositados milhares de anos após o evento. Parcialmente responsável para a manutenção das baixas temperaturas na superfície terrestre foi a atuação do efeito albedo (Hsü 1986),(c) após o resfriamento houve uma repentina elevação térmica no Paleoceno (Fig.3) atribuída por Hsü (1986) e Weissert \& Lini (1991) à redução do plancton oceânico e consequente incremento na liberação do $\mathrm{CO}_{2}$ para a atmosfera em magnitude tal que o valor excedia em três vêzes os atuais.

\section{CONDICIONAMENTO TECTÔNICO E REGISTROS GEOLÓGICOS}

O Cretáceo é um dos períodos do Fanerozóico melhor representados no Brasil e um dos mais estudados devido as ocorrências de hidrocarbonetos nas bacias costeiras. Tais bacias, assim como aquelas denominadas bacias interiores do Nordeste - não são objeto do presente estudo-, assim como suas correspondentes africanas, exibem feições características de clima árido no Cretáceo Inferior.

Segundo França et al. (1995), três eventos demonstraram a importância do Cretáceo para o Gondwana: (a) as bacias sedimentares formadas ao longo da costa leste da América do Sul resultantes da abertura do Atlântico Sul, (b) a transgressão marinha que afetou as partes andinas da Bolívia e Argentina e (c) o advento de um dos mais extensos vulcanismos de platô já registrados, representado pelas lavas basálticas do Grupo São Bento, mudando completamente as características geomorfológicas das bacias do Paraná e do Chaco.

Conforme observado por Petri (1991), a distribuição das rochas cretácicas em nosso País está íntimamente relacionada à feições estruturais antigas precambrianas reativadas no início do Cretáceo, durante a Reativação Wealdeniana (Almeida 1967a). 
$\mathrm{Na}$ parte centro-sul do país, estas estruturas condicionaram a sedimentação cretácica no interior do continente (Fig.4):

(a) o Arco de Assunção bordejando a Bacia do Paraná a oeste;

(b) o Arco do Alto Paranaíba (ou Arco da Canastra), delimitando as Bacias do Paraná e Sanfranciscana ;

(c) o Alinhamento de Pernambuco-Paraíba, bordejando a Bacia Sanfranciscana ao Norte;

(d) o Arco de Rondonópolis, delimitando as bacias do Parecis a NE e a do Paraná a SE.

$\mathrm{O}$ presente estudo priorizou as seguintes unidades estruturais -o Arco do Alto Paranaíba, a Bacia do Paraná, a Bacia Sanfranciscana e a Bacia dos Parecis-, as quais serão sumariamente descritas.

\section{O ARCO DO ALTO PARANAÍBA}

O Arco do Alto Paranaíba (AAP) (Ladeira et al. 1971), representa uma importante feição tectônica e orográfica do Oeste do Estado de Minas Gerais. Sua importância paleogeográfica foi primeiramente reconhecida por Costa (1963), que caracterizou-o como um arco que separava as duas bacias, do Paraná (Triângulo Mineiro) e Sanfranciscana, região do Alto Paranaíba (Fig.5).
Grossi Sad et al. (1971) e Petri (1991), estenderam a compreensão do AAP como uma unidade paleogeográfica mais antiga, propondo que o arco já atuava, no Cretáceo Inferior, como uma área elevada e limitante das bacias acima referidas.

O AAP insere-se na Faixa Brasília (Almeida 1967 b), uma região de dobramentos brasilianos (750-400 M.a.) alinhados na direção NNW-SSE. Bordejam a parte ocidental do Cráton do São Francisco, estendendose por cerca de $1000 \mathrm{Km}$ entre os paralelos $12^{\circ}$ e $21^{\circ} \mathrm{S}$. É formado da base para o topo por rochas proterozóicas representadas por quartzitos e filitos do Grupo Canastra, paraconglomerados e filitos calcíferos do Grupo Ibiá e xistos, filitos e quartzitos do Grupo Araxá ( Barbosa et al. 1970, Marini et al. 1978, Pereira et al. 1992,1994). Intrudindo esta última sequência ocorre uma suíte granítica sin a pós-tectônica, alcalina, perpotássica e peraluminosa, a qual assume importante papel no rastreamento das áreas fornecedores de detritos para as duas bacias cretácicas marginais, ao longo de todo o Cretáceo.

Os litossomas que compõem o AAP encontram-se atualmente preservados como sucessões de escamas de empurrões com vergência tectônica para leste, em direção ao Cráton do São Francisco. O movimento

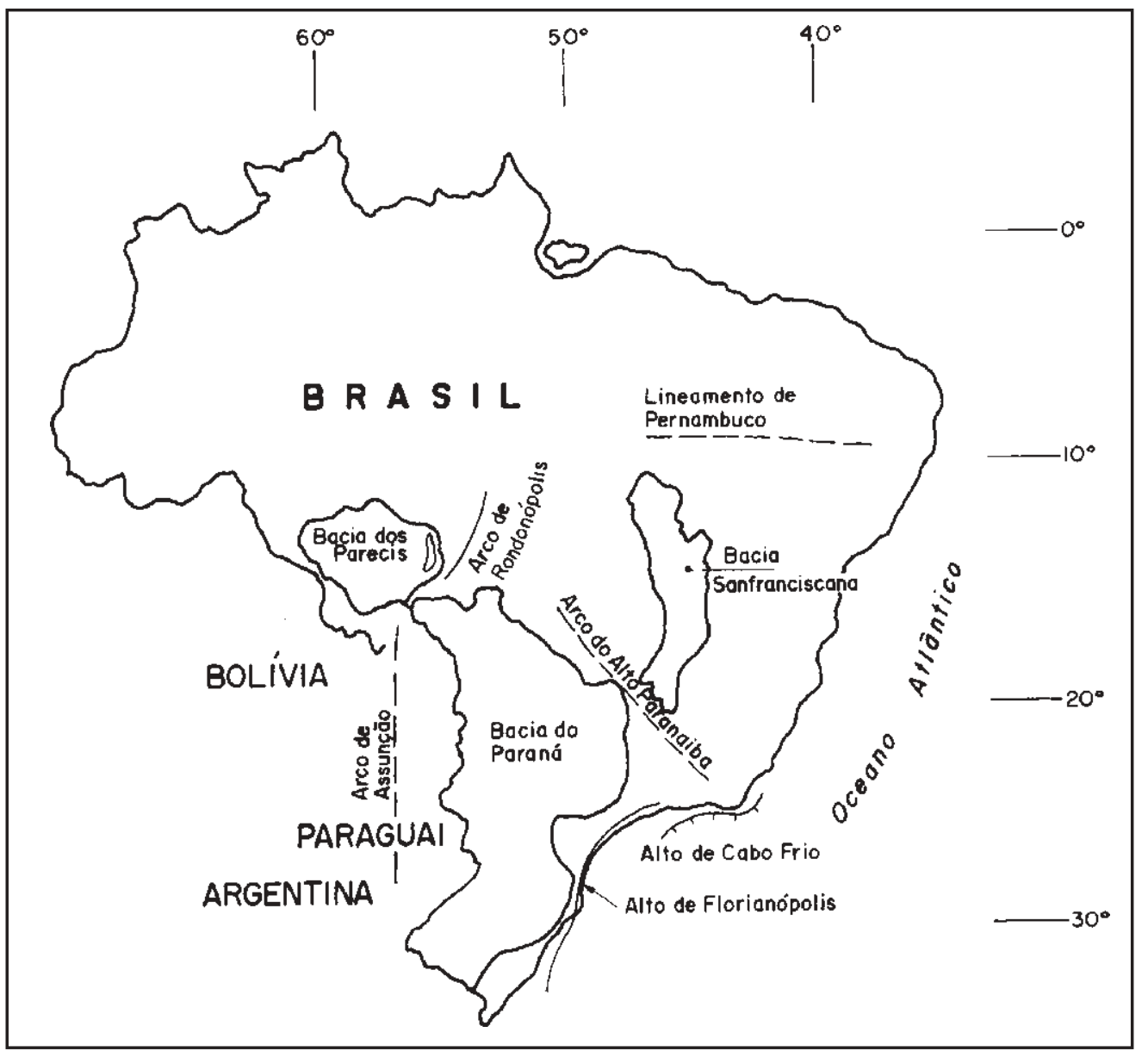

Figura 4: Localização das bacias investigadas, mostrando as relações spaciais entre ocorrências de rochas cretácicas com feições estruturais marginais antigas.

Figure 4: Location of the investigated basins, showing that the distribution of rocks of Cretaceous age in Central-South part of Brazil is strongly conditioned to old structural features. 


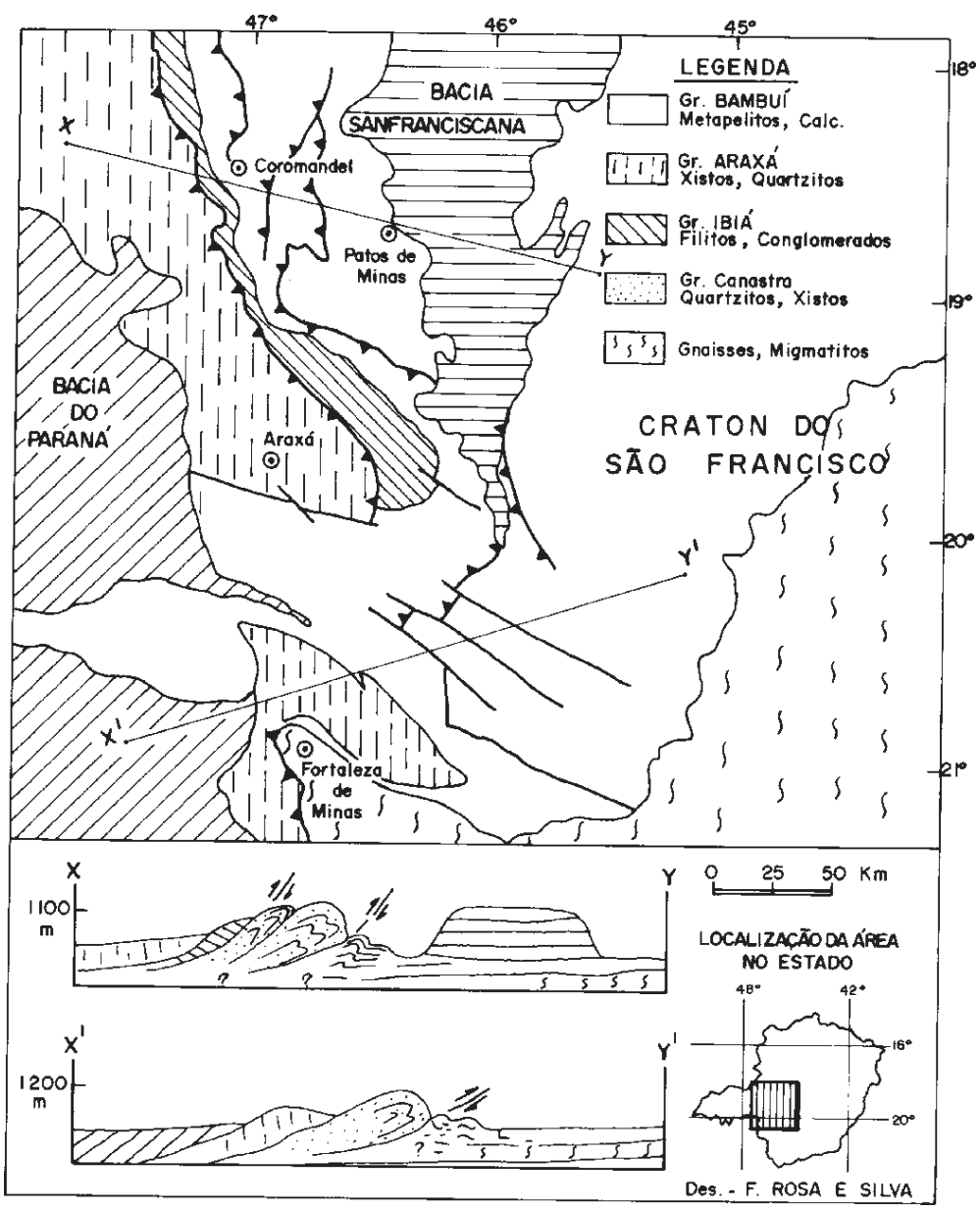

Figura 5: Mapa geológico e perfís esquemáticos mostrando o Arco do Alto Paranaíba-inserido na Faixa Brasília-e suas relações tectono-espaciais com as bacias marginais cretácicas do Paraná e Sanfranciscana. A situação mostra vergência tectônica das estruturas do arco para o Cráton do São Francisco, a leste. (Baseado em Schmidt 1983; Vaz de Melo, 1994).

Figura 5: Geologic map and schematic profiles showing the relationship between the Alto do Paranaiba Arch (Brasilia Belt) and the Paraná and Sanfranciscana basins. The tectonic vergence of the Arch is to Craton, positioned in the east (After Schmidt 1983; Vaz de Melo 1994).

englobou também, na borda oriental do Arco, metapelitos do Grupo Bambuí, que formam a cobertura cratônica regional. A faixa móvel foi, de acordo com Ramos (1988), Pimentel \& Fuck (1992), Unrug 1992, e Storey 1993 apud Gibson et al. (1995), resultante da colisão entre os crátons amazônico e/ou Rio da Prata com o Cráton do São Francisco, durante a amalgamação do continente Gondwana. Sua origem relaciona-se com a evolução de uma margem continental ativa no final do Proterozóico (Marini et al. 1981).

A morfologia do AAP na área enfocada (Fig.5) permite defini-lo como sendo a parte frontal de um sistema de nappes (Fuck et al. 1994). Tal fato pode ser observado tanto a sul, na região de Fortaleza de Minas, onde um cinturão dobrado ocorre na borda SW do Cráton do São Francisco com vergência tectônica para NE (Schmidt 1983) como também mais a norte na região de Coromandel, onde sequências alóctones dos Grupos Araxá e Canastra formadas por xistos e quartzitos deslocaram-se como nappes em direção ao cráton situado a leste. Feições tectônicas do tipo alpino, similares às existentes no AAP podem ser encontradas em Schmidt \& Bögel (1976) e Windley (1979).

Evidências sedimentológicas citadas indicam que o AAP tinha, desde o Paleozóico, uma magnitude altimétrica muito superior à atual. Fenômenos erosivos que o arrasaram na região de Goiás, também atuaram, embora em menor escala, em suas partes frontais relacionadas ao presente estudo, degradando a antiga cordilheira aos níveis atualmente observados. Pitman \& Golovchenko (1991), mostraram dados que permitem inferir um período de cerca de 150 M.a. para a degradação altimétrica de uma cordilheira como a atual Himalaia quando submetida a processos convencionais de erosão, sendo que a compensação isostática prolongaria o processo. Litologias quimicamente resistentes como quartzitos e cherts poderiam sobreviver a períodos mais longos. Mesmo levando-se em conta que margens convergentes recentes geram cadeias dobradas com maiores magnitudes que as do Proterozóico, o isolamento de fontes úmidas no interior do Gondwana, poderia prolongar por mais tempo a 
permanência do relevo.

A compreensão da evolução tectônica do oeste mineiro, com enfoque para a sedimentação cretácia associada, recebeu considerável impulso com os estudos de Hasuiet al. (1975) e Hasui \& Haralyi (1991). Eles associaram o início da deposição da Bacia Sanfranciscana, no Cretáceo Inferior, à reativação tectônica que afetou o AAP, pioneiramente reconhecida e estendida por amplas porções da plataforma brasileira por Almeida (1967a). Falhamentos extensionais envolvendo fraturas préexistentes no embasamento, com direções NNE-SSW desenvolveram-se na borda oriental do AAP, palco da sedimentação Areado. Do outro lado do Arco, o embaciamento na borda NNE da Bacia do Paraná desenvolvido sobre os sedimentos paleozóicos e porções do embasamento Précambriano, foi preenchido pelos arenitos e conglomerados da Formação Botucatu e pelas lavas da Formação Serra Geral do Grupo São Bento.

O comportamento do AAP como um alto estrutural estende-se desde o paleozóico, tendo limitado a extensão da bacia paleozóica do Paraná para além de seus limites NE atuais. No Juro-Cretácico, serviu também de barreira ao avanço tanto do deserto Botucatu como das lavas Serra Geral.

Sgarbi \& Ladeira (1995a) e Sgarbi (1996a,b), atribuiram ao AAP durante o Cretáceo Inferior importante papel no fornecimento contínuo e abundante de clastos de quartzito, quartzo e granito presentes em conglomerados de ambas as bacias cretácicas marginais. No caso da Bacia Sanfranciscana, clastos de quartzitos e granitos podem ser observados compondo seus conglomerados basais, constituindo leques aluviais, depósitos do tipo wadi e depósitos fluviais, este últimos dispostos em extensas áreas distantes a centenas de quilômetros a norte e nordeste do AAP. Tais sedimentos do Cretáceo Inferior refletem ainda a existência de movimentação tectônica do substrato, síncrona com sua deposição, conforme mostram falhas inversas cortando os sedimentos basais da bacia (Sgarbi 1989).

No Cretáceo Superior, nova reativação síncrona com o magmatismo alcalino afetou a região do AAP. Tanto em suas vertentes ocidentais -Bacia do Paranácomo nas orientais -Bacia Sanfranciscana - formaramse depósitos de rochas epiclásticas formando leques aluviais. Na vertente oriental, esse aporte epiclástico além de mais efetivo, associou-se a derrames de lavas e níveis piroclásticos, indicando, na Bacia Sanfranciscana, a simultaneidade do vulcanismo com a erosão e deposição clástica.

A parte voltada para a Bacia do Paraná recebeu, aparentemente em menor escala, a sedimentação epiclástica originária do AAP, igualmente na forma de lençóis de escoamento formando leques aluviais proximais ao arco e depósitos fluviais distais, a oeste. Ao contrário do que ocorreu na Bacia Sanfranciscana, nesse local o nível de base não foi alcançado pela sedimentação epiclástica. Leques aluviais provenientes do arco continuaram o preenchimento da Bacia de Uberaba mesmo após a completa remoção dos remanescentes vulcânicos da área fonte, de maneira que o pacote epiclástico encontra-se cobertos por ruditos não vulcânicos.

\section{BACIA DO PARANÁ}

\section{Grupo São Bento, Formação Botucatu}

Em termos de área de ocorrência, a sedimentação mais importante do Cretáceo continental brasileiro é representada pela Formação Botucatu do Grupo São Bento, representativa de um mega sistema desértico que se instalou, possivelmente ainda no Jurássico Superior, mas que se desenvolveu em sua maior plenitude no Cretáceo Inferior.

O Deserto Botucatu dominou amplamente os registros geológicos pré-existentes na bacia do Paraná e adjacências. De acordo com observações de afloramentos parcialmente erodidos que ocorrem em áreas marginais à bacia, o deserto ocupou uma área superior a 1,5 x 106 $\mathrm{Km}^{2}$ (Bigarella \& Salamuni 1961), cobrindo grande parte do Sudeste e Sul do País, alcançando ainda a Argentina, Uruguai e Paraguai (Bigarella \& Salamuni 1961, Wiens 1986, Camino 1986, Carta Geol.del Uruguay 1974). Com 250 metros de espessura média, trata-se, segundo Bigarella (1949), Almeida (1954) e Cottas et al. (1986), de um arenito vermelho, fino a médio, com estratificações cruzadas de grande porte, bem selecionado, mostrando grãos policíclicos tamanho areia fina a média com alta esfericidade e com poucos resíduos pesados. Mostra intercalações de pequenos corpos flúvio-lacustrinos na base e importantes intercalações com a seqüência vulcânica a êle superposta em suas partes média e superior, como será mostrado adiante (Fig.6A).

A parte setentrional do deserto, posicionada entre os paralelos $10^{\circ} \mathrm{S}$ e $20^{\circ} \mathrm{S}$, expunha-se às células de pressão atmosférica tropical desenvolvidas no centro do Gondwana, as quais geravam ventos anti-horários direcionados de NE para SW e de N para S (Bigarella \& Salamuni 1961, Lloyd 1981). Direções de paleocorrentes, com sentidos semelhantes, obtidas de estratos frontais de dunas eólicas, na parte norte da bacia foram descritas por Bigarella e Salamuni (1961). As áreas fontes mais prováveis teriam sido os quartzitos de baixo grau metamórfico que ocorrem na Faixa Brasília -na qual insere-se o Arco do Alto Paranaíba descrito adiante- e da Cordilheira do Espinhaço, além dos terrenos metamórficos de alto grau que formam embasamento regional.

Ao sul da Bacia do Paraná, células de pressão geradas entre os paralelos $20^{\circ} \mathrm{S}$ e $40^{\circ} \mathrm{S}$ desenvolviamse sobre a parte oriental do Pacífico, adentrando o continente de SW par NE e de S para N (Bigarella \& Salamuni 1961, Lloyd 1981). A erosão incidiu sobre as rochas adjacentes ao Deserto Botucatu, afetando notadamente os sedimentos arenosos do Grupo Tubarão e Formação Aquidauana, que atuaram como 
importante área de proveniência local. Conforme observado por Almeida (1954), a natureza arenosa dos depósitos das áreas de proveniência contribuiu para o estabelecimento deste vasto deserto, assim como também a topografia plana da Bacia do Paraná auxiliou na livre progressão das dunas, em um modelo parecido com o atual Sahara. Paleocorrentes obtidas por Bigarella e Salamuni (1961) a partir de estratificações cruzadas mostram, na parte meridional do Deserto Botucatu, sentidos de paleoventos semelhantes aos anteriormente descritos (para NE e N). Depósitos lacustres associados a pavimentos de deflação onde se desenvolviam oueds foram descritos por Almeida (1954) na parte basal da seqüência Botucatu. Desconhecem-se ocorrências deste fácies em suas partes médias e superiores, fato que indica a existência de um ciclo evolutivo variando de uma fase de entulhamento da topografia, com acúmulo de umidade em suas partes baixas, com uma rede de drenagem ainda atuante, para a instalação do deserto de grande porte, com imensos depósitos de ergs afogando e desorganizando a antiga drenagem subjacente. Nesta fase predominou a infiltração e perda súbita das águas superficiais, caracterizando um ambiente extremamente árido.

Dados geocrononógicos acerca da Formação Botucatu foram reportados por Leonardi (1980) e Leonardi \& Lima (1990), baseados na comparação de associação de impressões de tetrápodos observados em São Paulo e na Argentina. Tais autores atribuiram ao Botucatu idade posicionada entre o Jurássico Inferior e Médio. Entretanto, Musa (1974), atribuiu à esta formação, idade cretácica inferior, com base no estudo de peças silicificadas de madeiras do grupo das Protopinaceae.

Recentes dados geocronológicos e de campo foram reportados por Peate et al. (1992), os quais mostraram que estes arenitos eólicos são encontrados intercalados na sequência basáltica superior do Grupo São Bento,representada pela Formação Serra Geral - até pelo menos na metade da pilha vulcânica. Tais lavas exibem cerca de 1800 metros de espessura máxima e derrames individuais de até $80 \mathrm{~m}$ de espessura (Almeida 1954, Asmus \& Porto 1972) (Fig.6A).

Níveis de brechas associados aos arenitos eólicos Botucatu foram observados na parte NE da Bacia do Paraná nas imediações do Arco do Alto Paranaíba (Fig. 6A) no Oeste do Estado de Minas Gerais (Sgarbi 1996a,1996b). Relacionam-se com movimentos de blocos do embasamento formando escarpas, em época imediatamente anterior ao início do vulcanismo Serra Geral, associados possivelmente com os esforços intraplaca da futura fragmentação que daria origem ao Atlântico Sul.

As brechas são matriz-suportadas, originárias por fluxo gravitacional, com espessuras que chegam aos $10 \mathrm{~m}$. Localmente silicificadas, mostram clastos de rochas do embasamento -anfibolito, quartzito, granito, quartzo; alguns seixos são facetados por ação eólica- envoltos em uma matriz arenosa constituída por grãos arredondados de origem eólica. Alguns afloramentos foram cobertos por cerca de $200 \mathrm{~m}$ de basaltos, em vários derrames (Sgarbi 1996b).

Rivarela \& Di Paolo (1992) descreveram também seqüências eólicas associadas a derrames basálticos da Serra de Las Quijadas, província de São Luís, Argentina, de idade neo-Jurássica/eo-Cretácica, correlacionadas ao Arenito Botucatu. Mostram sentidos de transportes para $\mathrm{N}$ e $\mathrm{NW}$ e encerram restos de Iguanodon, sendo cobertas por depósitos fluviais e lacustres até culminar, ao final do Cretáceo, com deposição de gipsita, indicando a substituição da sedimentação clástica por química. O pacote, de cerca de 1000 metros de espessura, indica também variações paleoclimáticas em ambiente desértico. Nesse país, o Arenito Botucatu assume a designação de Membro Solari da Formação Curuzu-Cuatia.

\section{Grupo São Bento, Formação Serra Geral}

Manifestações magmáticas de caráter básico afetaram amplas porções das terras então emersas no Mesozóico, iniciando-se quando areias com espessuras locais de 120 metros já haviam sido depositadas (Almeida 1954). A Província Vulcânica do Paraná é representada pela Formação Serra Geral do Grupo São Bento. Juntamente com a pequena província de Etendeka do Sudoeste da África (Namíbia), a qual mostra uma área de cerca de $0.08 \times 10^{6} \mathrm{Km}^{2}$ e idade em torno de 130-120 M.a.(Richards et al. 1989), constitui uma única província magmática formada durante os estágios iniciais da abertura do Atlântico Sul, no Cretáceo Inferior. Elas constituem uma das maiores províncias magmáticas do planeta, sendo formadas por basaltos toleíiticos e basaltos andesíticos, com significantes quantidades de riolitos e riodacitos também presentes (Peate et al. 1992).

A província cobre atualmente, na América do Sul, uma área de 1,2 ×10 $0^{6} \mathrm{Km}^{2}$ do Brasil, Argentina, Uruguai e Paraguai e provavelmente cobriu originalmente uma área de cerca de $2,0 \times 10^{6} \mathrm{Km}^{2}$ (Rampino \& Stothers 1988), a julgar pelos afloramentos marginais à bacia. Duas áreas de máxima espessura basáltica ocorrem uma ao norte, no Estado de São Paulo (1800 m de espessura de basalto) e outra ao sul, na área do rio Uruguai, exibindo espessura de $1200 \mathrm{~m}$ de basalto. A espessura média é estimada em $650 \mathrm{~m}$, com um volume total de 1,3 x $10^{6} \mathrm{Km}^{3}$ (Bizzi 1993).

Os derrames basalticos, que sucederam aos basaltos Serra Geral, espalharam-se por uma superfície muito irregular, entulhando depressões interdunas e os vales naturais escavados nos arenitos sotopostos (Fig. 6A).

As idades mais recentes das lavas Serra Geral mostram valores para o vulcanismo situado entre 135130 M.a. (Hauteriviano-Valenginiano/Barremiano Inferior, segundo a escala geocronológica de Harland et al 1989) (Tabela 2).

Brechas monomícticas basálticas mostrando matriz arenosa eólica ocorrem intercaladas a níveis de 
derrames na mesma região. Foram depositadas por fluxos de detritos de leques aluviais e depósitos coluvionares formados em escarpas de falhas desenvolvidas nos níveis superiores do próprio basalto. Alcançam até $60 \mathrm{~m}$ de espessura, indicando a continuidade tectônica associada aos derrames basálticos, embora provavelmente muitas ocorrências relacionam-se à simples retração de escarpas.

\section{Grupo Bauru}

A Bacia Bauru, implantada entre o Santoniano e Maastrichtiano (Riccomini 1996) na porção centronorte da Bacia do Paraná (Figs.4 e 5) constitui uma bacia tectonicamente distinta desta. Fulfaro \& Perinotto (1996) atribuem sua gênese à atuação de mecanismos térmicos associados aos processos conjugados de ruptura e deriva que afetaram o interior da placa sulamericana, sendo ainda diferenciada dos ciclos sedimentares precedentes da Bacia do Paraná.

Em uma área de $350000 \mathrm{Km}^{2}$, a bacia sucedeu os derrames basálticos da Bacia do Paraná nos Estados de Minas Gerais, São Paulo, Mato Grosso do Sul e Paraná. Soares et al. (1980) dividiram o Grupo Bauru da base para o topo, nas formações Caiuá, Santo Anastácio, Adamantina e Marília. Constitue-se predominantemente por sedimentos arenosos, mostrando espessura máxima de 630 metros, formando um dos mais importantes e variados registros continentais do Cretáceo no País. Inicia-se pela Formação Caiuá constituída por conglomerados e lamitos basais localizados, seguidos pelos arenitos eólicos característicos da formação, depositados após um ciclo erosivo, sobre basaltos da Formação Serra Geral. Soares et al. (1980) descreveram o contato entre as duas unidades, mostrando a ocorrência de paleossolos sobre os basaltos e ausência de brecha de topo na superfície destes, concluindo pela existência de clima úmido que sucedeu imediatamente os derrames. Alcança até 250 metros de espessura no leste do Paraná (Landim e Soares 1976). Sua principal área fonte situava-se a Oeste, com decréscimo de granulometria para leste, conforme mostrou Saad et al. (1988).

Fulfaro \& Barcelos (1991) atribuiram ao Caiuá uma origem balisada por rifteamento pós-magmatismo Serra Geral, fato que originou a a instalação de uma bacia fechada endorréica, que recebeu a sedimentação eólica.

Leonardi (1977) posicionou o Arenito Caiuá no Cretáceo Médio com base em ichnofaunas reptilianas. Sua instalação parece ter coincidido com a mudança climática ocorrida no intervalo Albiano-Cenomaniano (Suguio \& Barcelos 1983), período que correspondeu, segundo Hsü (1992), ao ápice da aridez no Cretáceo, na passagem do topo do Cretáceo Inferior para a base do Superior.

Seguem-se arenitos finos resultantes de deposição fluvio-anostomosada, além de lacustre, pertencentes à Formação Santo Anastácio. Ela reflete a evolução de um ambiente desértico severo para um outro similar porém com mais umidade, dentro do mesmo contexto paleogeográfico. Exibe as mesmas áreas de proveniência que o Caiuá, iniciando-se com depósitos de fluxos de detritos gradando para arenitos finos. $\mathrm{O}$ clima semi-árido é constatado pelas ocorrências de calcretes descritas por Barcelos \& Suguio (1983) e Saad et al (1988).

A Formação Adamantina mostra a intensificação do clima úmido na região, constituindo o período climaticamente mais ameno da sedimentação Bauru, apesar de mostrar episódios cíclicos e curtos de aquecimento, conforme atestam os níveis de calcretes mostrados por Suguio e Barcelos (1983). Com espessura máxima de 93 metros, transgride as formações precedentes, assentando-se localmente sobre os basaltos da Formação Serra Geral. Inicia-se com conglomerados basais com seixos de basalto, seguidos por dois bem marcados ciclos arenosos entremeados com lamitos que podem alcançar 70 metros de espessura. Enquanto as áreas fontes mostram, para os termos basais, terrenos situados a oeste, seu topo exibe fontes múltiplas, caracterizando uma reestruturação tectônica da bacia (Saad et al. 1988). Seu topo mostra intercalações de lavas alcalinas analcimíticas, episódios provavelmente relacionados com o magmatismo alcalino do Alto Paranaíba que afetou a Bacia Sanfranciscana, no Turoniano-Coniaciano. Evidência de ambiente propício à vida durante a sedimentação Adamantina é demonstrada pelo seu importante conteúdo fossilífero. Ela encerra alguns dos mais importantes jazigos fossilíferos continentais do Cretáceo Superior do País, conforme atestam Petri (1955), Mezzalira (1974,1980) e Bertini (1996 a,b), os quais citaram ocorrências de fósseis reptlianos Archosaria Theropoda, Sauropoda, Crocodilia, Chelonia, além outros como Crustacea, Mammalia e Algae. Peixes Lepisosteiformes, Osteoglossiformes e Siluriformes foram descritos por Gayet e Marques-Brito (1989).

Superpondo-se à Formação Adamantina ocorre a Formação Marília, indicando a retomada de um clima extremamente árido na bacia, no Maastrichtiano (Suguio \& Barcelos 1983, Petri 1983). É constituinda por arenitos conglomeráticos e conglomerados polimícticos, cimentados por carbonato de cálcio, depositados predominantemente por lençois de escoamento formando leques aluviais e por rios entrelaçados. Contém também um importantes registro fossilífero continental do Cretáceo Superior, na forma de restos reptilianos incluindo Archosauria Theropoda e Sauropoda além de Crocodilia e Chelonia (Price 1950, 1953; Brito \& Almeida-Campos 1982), anuros Baurubatrachus pricei nov.gen.et esp. (Baez \& Peri 1989), além de peixes Lepisosteiformes, Characiformes e possivelmente Preciformes (Gayet \& Marques-Brito 1989).

No Triângulo Mineiro, no nordeste da Bacia do Paraná, o Grupo Bauru apresenta perculiaridades. Constitue-se apenas pelas formações Uberaba (Hasui 1968) e Marília (Fig.6B), sendo que a primeira foi 


\begin{tabular}{|c|c|c|c|}
\hline $\begin{array}{c}\text { Creer et al. (1965). Nature } \\
\text { 207:282-283 }\end{array}$ & Ing. & $\mathrm{K} / \mathrm{Ar}$ (r.t.) & 140 \\
\hline $\begin{array}{c}\text { Amaral et al. (1966). } \\
\text { Geoch.Cosm.Acta.30:159-18 }\end{array}$ & Ing. & $\begin{array}{l}\mathrm{K} / \mathrm{Ar} \\
(\mathrm{W} . \mathrm{r})\end{array}$ & $\begin{array}{c}\text { Concentração = } \\
135-115 \\
\text { Idade preferida }=120 \\
\text { Vulcanismo Precursor }= \\
147\end{array}$ \\
\hline $\begin{array}{l}\text { McDougall \& Rueg (1966). } \\
\text { Geoch.Cosm.Acta.30:191-19 }\end{array}$ & Ing. & $\begin{array}{l}\mathrm{K} / \mathrm{Ar} \\
(\mathrm{pl}, \mathrm{py})\end{array}$ & $120-126$ \\
\hline $\begin{array}{c}\text { Cordani \& Vandoros (1967) in } \\
\text { Cox 1978. Intern. Simp. } \\
\text { Gondwana,Ver Cox (1978). }\end{array}$ & Ing. & $\mathrm{K} / \mathrm{Ar}$ & 125 \\
\hline $\begin{array}{c}\text { Mantovani et al. } 1985 . \\
\text { Rev.bras.Geoc.,15:61-65. }\end{array}$ & Port. & $\begin{array}{c}\mathrm{K} / \mathrm{Ar}(\mathrm{py}) \\
\mathrm{Rb} / \mathrm{Sr} \\
(\mathrm{pl})\end{array}$ & $\begin{array}{c}\text { 123.8+/-1.6-129.9+/-1.6 } \\
\text { (Idade mínima-perda de } \\
\text { argônio) } \\
131,8+/-5,9-138,4+/-3,5 \\
\text { Idade } \\
\text { Preferencial=135.4 } \\
+/-3.5\end{array}$ \\
\hline \begin{tabular}{|c|} 
Mantovani et al. \\
(1985).Jour.Petrology,26:187
\end{tabular} & Ing. & $?$ & $\begin{array}{c}\text { 147-119 variação; } \\
130-120 \text { concentração }\end{array}$ \\
\hline $\begin{array}{c}\text { Fodor \& Vetter (1985). } \\
\text { Rev.Bras.Geoc.,15:(1):36-47 }\end{array}$ & Ing & $\mathrm{K} / \mathrm{Ar}$ (r.t.) & $\begin{array}{c}\text { 138.1+/-3.5-104.9 +/-2.6 } \\
\text { Média }=121.1\end{array}$ \\
\hline $\begin{array}{c}\text { Morgan, (1986). } \\
\text { Eos-AGU, 67(16), p. } 391 .\end{array}$ & Ing & $?$ & $135-125$ \\
\hline $\begin{array}{c}\text { Several authors in Rampino } \\
\& \text { Stothers (1988). Science } \\
241: 663-669 .\end{array}$ & Ing & $\mathrm{K} / \mathrm{Ar}$ (r.t.) & $\mathrm{Rb} / \mathrm{Sr}$ \\
\hline $\begin{array}{l}\text { Melfi et al.(1967); Amaral et } \\
\text { al. } 1966 \text { in Peate et al. } \\
\text { (1988). } \\
\text { Rev.Bras.Geoc.,18:212-221. }\end{array}$ & Ing & K/Ar (r.t.) & $\begin{array}{l}130 \text { - Idade preferida } \\
\text { variação = 115-135 }\end{array}$ \\
\hline $\begin{array}{l}\text { Rocha Campos et al.1988. } \\
\text { Mesozoic Paraná Flood } \\
\text { Volcanism. IAG-USP,1988, } \\
\text { p. } 25-45 .\end{array}$ & Ing & \begin{tabular}{|c|}
$\mathrm{K} / \mathrm{Ar}$ \\
(r.t.PI.Py. \\
$\mathrm{Fsp})$. \\
$\mathrm{Rb} / \mathrm{Sr}$ \\
(PI., r.t.) \\
matriz
\end{tabular} & $\begin{array}{c}150-110 \text { principal em } \\
127 \\
\text { riodacitos=135.5+/-3.2 } \\
\text { Principal fase } \\
\text { eruptiva }=135-130\end{array}$ \\
\hline $\begin{array}{c}\text { Pinese (1988), Rocha } \\
\text { Campos et al. (1988) in } \\
\text { Piccirillo et al. 1990. Chem. } \\
\text { Geology, 89:119-148. }\end{array}$ & Ing & K-Ar(r.t.) & $\begin{array}{c}\text { 132+/-10 (diques), } \\
\text { variação=114-144 } \\
\text { 131+/-9 (derrames) } \\
\text { variação 112-155 } \\
\text { (derrames) }\end{array}$ \\
\hline $\begin{array}{l}\text { Baksi et al. (1991). } \\
\text { Eos-AGU, p.300. }\end{array}$ & Ing & $\mathrm{Ar} / \mathrm{Ar}$ & $\begin{array}{c}\text { Início }=135 \\
\text { Término }=130\end{array}$ \\
\hline $\begin{array}{c}\text { Hawkesworth et al. (1991) } \\
\text { in Renne et al. 1992. } \\
\text { Science 258: 975-979. }\end{array}$ & Ing & $\operatorname{Ar} / \operatorname{Ar}($ r.t. $)$ & $\begin{array}{c}133+/-2 \text { e } 132+/-1 \\
\text { (basaltos inferiores) } \\
\text { início=135 término=130 }\end{array}$ \\
\hline $\begin{array}{l}\text { Peate et al. 1992. Bull. } \\
\text { Volcan., 55: 119-139. }\end{array}$ & Ing. & $\mathrm{K} / \mathrm{Ar}$ & $\begin{array}{c}135 \text { - } 115 \text { (lava) } \\
130 \text { Idade mínima }\end{array}$ \\
\hline $\begin{array}{c}\text { Stewart et al. } 1994 \text { in Garland } \\
\text { et al. (1994). } \\
\text { Min. Magaz. 58A: 317-318. }\end{array}$ & Ing & $\mathrm{Ar} / \mathrm{Ar}$ & $\begin{array}{c}\text { Mais antigos basaltos = } \\
138 \text { (extremo NW da } \\
\text { bacia); Basaltos mais } \\
\text { jovens }=127 \text { (SE borda } \\
\text { da bacia) }\end{array}$ \\
\hline \begin{tabular}{|c|} 
Turner et al. (1994). Earth \\
Plan. Sci. Let., 121: 333-348.
\end{tabular} & Ing & $\mathrm{Ar} / \mathrm{Ar}$ & Entre $137-127$ \\
\hline $\begin{array}{l}\text { Gallagher et al. (1995). } \\
\text { Journ. S. Amer. Eart. Sci., } \\
\text { 8:65-77. }\end{array}$ & Ing & $\begin{array}{c}\text { Fission - } \\
\text { Track } \\
\text { data }\end{array}$ & $\sim 130$ \\
\hline $\begin{array}{c}\text { França et al. (1995). AAPG } \\
\text { Memoir 62:129-161. }\end{array}$ & Ing. & $?$ & $144-119$ \\
\hline
\end{tabular}

Tabela 2. Evolução do conhecimento geocronológico da Formação Serra Geral, Grupo São Bento, Bacia do Paraná.

Table 2. Geochronological data of the Serra Geral Formation, São Bento Group, Paraná Basin. 
correlacionada lateralmente à Formação Adamantina por Barcelos et al. (1987). Ambas mostram a retomada da reativação tectonica nas áreas altas situadas a leste, no AAP.

A Formação Uberaba, na região, é constituída por arenitos, lamitos e conglomerados, epiclásticos, de origem fluvial, indicando abundância de água no ambiente. Depositou-se sobre o relevo ondulado basáltico da Formação Serra Geral, sendo deste separada por uma discordância erosiva. Sobre os basaltos, frescos, ocorre um delgado nível de brecha sedimentar areno-siltosa constituída por fragmentos inalterados de basalto. A Formação Uberaba exibe cerca de 80 metros de espessura máxima, sendo constituída por arenito lítico verde, médio a fino, bem arredondado e cimentado por carbonato e cálcio. Intercalações de siltitos vermelhos ocorrem formando corpos sigmoidais entremeados na sequência fluvial. Os fragmentos são predominantemente formados por rochas vulcânicas alcalinas, às quais se juntam subordinadamente clastos de basaltos, rochas metamórficas do embasamento e arenitos silicificados da Formação Botucatu. São extremamente susceptíveis à alteração química, gerando um relevo plano com profundos perfís de intemperismo, semelhantes aos dos basaltos e uma variada assembléia de minerais secundários como esmectitas, zeólitas e anatásio. Estes arenitos vulcânicos são importantes sob o ponto de vista da raridade, uma vez que dentro do contexto geológico do Mesozóico do País, predominam, quase que em termos absolutos, quartzo-arenitos. Potter (1994) em um estudo sobre as areias modernas da América do Sul, as quais podem ser interpretadas como um reflexo de suas áreas fontes, mostrou que, no âmbito do nosso continente - incluíndo as províncias sedimentares andina e argentina- as areias líticas perfazem apenas $7 \%$ do total com as vulcânicas alcançando $4 \%$ deste valor.

Barcelos (1989), baseado na variação faciológica e em estruturas direcionais, registrou, para tal formação, transporte de leste para oeste, com a área de proveniência localizada na região do Arco do Alto Paranaíba.

Hussak (1906) já chamara a atenção para a filiação alcalina dos constituintes vulcânicos desta sequência, com base em sua assembéia de minerais, contendo perovskita e magnetita. Sgarbi (1996c), com base em estudos microanalíticos identificou o diopsídio como o principal clinopiroxênio existente tanto nos clástos vulcânicos como na matriz dos arenitos da Formação Uberaba, comprovando uma fonte relacionada com as rochas alcalinas que ocorrem no AAP. O mesmo estudo mostrou a relativa ausência de augita e Fe-augita, piroxênios típicos dos basaltos que servem de substrato a esses sedimentos. A conclusão é que a deposição dos arenitos da Formação Uberaba deu-se em uma bacia exorréica, não incorporando de modo sinificativo contribuições de seu substrato basáltico (Fig. 6B).

Os basaltos Serra Geral mostram idades variando entre 135-130 M.a.,Tabela 2. A ausência, tanto de alteração intempérica como de brechas de colapso nestes basaltos, os quais foram recobertos por seqüências originárias da erosão de rochas vulcânicas alcalinas com idades variando grosso modo entre 90 a 80 M.a. (Ulbrich \& Gomes 1981, Gibson et al. 1995), tem uma importante conotação paleoclimática. O fato implica na atuação de um longo período seco decorrente entre o final dos derrames Serra Geral e a deposição dos arenitos Uberaba. Este intervalo erosivo não propiciou a deposição de rochas correlatas às formações Caiuá e Santo Anastácio na região, conforme ocorreu em outras parte da Bacia Bauru.

No Triângulo Mineiro, a Formação Marília (Fig. 6B) foi dividida por Barcelos et al. (1981), da base para o topo, nos membros Ponte Alta e Serra da Galga. Superpõe-se aos arenitos vulcânicos Uberaba segundo um contato gradacional (Lara 1993). O Membro Ponte Alta, com espessura média de $60 \mathrm{~m}$, é formado por arenitos e conglomerados calcíferos, exibindo estruturas erosionais e de preenchimento. Geralmente forma relevo escarpado devido a sua intensa cimentação carbonática. Nódulos de silcretes maciços na forma de opala e calcedônia, minerais do grupo da atapulgita (Suguio e Barcelos 1983), assim como a presença de argilas mecanicamente infiltradas diagnosticam um ambiente árido. Sua base exibe um nível de conglomerado com expessura até decamétrica, conhecido como "casco de burro", contendo ventifactos descritos por Pires (1982) e Barbosa e Castro (1992). Seu topo mostra um notável e constante horizonte de calcrete, atingindo $8 \mathrm{~m}$ de espessura, descrito por Suguio e Barcelos (1983) e Silva et al. (1994). Esse nível é beneficiado em uma planta de cimento Portland na região. O Membro Serra da Galga constitue-se por intercalações de arenitos imaturos e conglomerados friáveis, localmente calcíferos, mostrando estruturas erosivas, pelotas de argila e estratos cruzados. Mostra espessura média de $60 \mathrm{~m}$ e sentido de transporte para oeste.

Essa parte da Bacia Bauru, no membro Serra da Galga, situada a Oeste do AAP encerra também um importante jazigo fossilífero do Cretáceo Superior, com o predomínio de restos de dinossauros, evidenciando um ambiente propício a vida. A região parece ter-se constituído um abrigo, dentro do contexto desértico regional, e as causas podem ser atribuídas à influência do vizinho Arco do Alto Paranaíba.

Sabe-se que cordilheiras têm importante influência na circulação atmosférica e na precipitação pluviométrica (Ziegler et al. 1996). O arco, orientado no sentido NS, consituiu uma barreira natural à ação dos ventos que circulavam segundo células anti-horárias com movimento de NE para SW (Bigarella \& Salamuni 1961, Lloyd 1982), expondo as áreas adjacentes, situados a NE do arco à intensificação do domínio climático árido pela remoção da umidade superficial. A área protegida, situada a $\mathrm{W}$ do arco era, possivelmente, palco de chuvas orogenéticas que 
propiciaram a ocorrência de vegetação e umidade suficientes ao longo das encostas e vertentes do arco, proporcionando a existência de vegetação tipo savana nos campos abertos a juzante. Uma prova de que o local constituia-se um nicho consiste no fato de que as áreas circundantes crono-correlatas (como p.e. a Bacia Sanfranciscana) chamam a atenção - a par da descrição de impressões de pegadas atribuídas a dinossauros (Kattah 1994)- pela ausência de restos de animais de médio a grande porte, evidenciando a influência de um severo regime desértico regional.

\section{A BACIA SANFRANCISCANA}

A Bacia Sanfranciscana posiciona-se a Nordeste da Bacia do Paraná, sendo desta separada pelo Arco do Alto Paranaíba (Figs. 4 e 5). Possui uma forma alongada com cerca de $1100 \mathrm{Km}$ na direção N-S, entre as longitudes $44^{\circ}$ e $47^{\circ} \mathrm{W}$, alcançando uma largura máxima de $270 \mathrm{Km}$. Ocorre desde o Oeste do Estado de Minas Gerais em latitude próxima à $20^{\circ} \mathrm{S}$ até a parte meridional dos estados do Piauí e Maranhão, nas imediações da latitude $10^{\circ} \mathrm{S}$. Possui como substrato, do sul para norte, os sedimentos proterozóicos do Grupo Bambuí, os sedimentos glaciogênicos do Grupo Santa Fé, granitóides do embasamento e os sedimentos paleozóicos da Bacia do Maranhão.

A presente década trouxe importantes e inéditas contribuições ao conhecimento paleogeográfico da sedimentação no Gondwana central. Relacionam-se com a Bacia Sanfranciscana e mostram a necessidade de se incrementar o estudo das bacias cretácicas continentais do País:

(a) Kattah (1991) e Kattah \& Koutsoukos (1992) reconheceram radiolários e dinoflagelados marinhos em um delgado nível de silexito intercalado em sequências eólicas do Grupo Areado. Postulou então uma ingressão marinha originária do Norte, que teria alcançado o Oeste de Minas Gerais em alguma época do Cretáceo Inferior. Posteriormente, Pessagno (1995 informação escrita) e Dimas-Brito \& Pessagno (1996), reconheceram, nos silexitos, os taxons Parvicingula, Caneta e Noviforemanella, originários do neokimmeridgiano (Neojurássico) ao neovalanginiano (Eocretáceo). Ainda conforme os citados autores, sabese que o radiolário Parvicingula origina-se de massas de água situadas em paleolatitudes superiores a $22^{\circ} \mathrm{S}$ e que dados paleobatimétricos indicaram para o silextito valores superiores a 150 metros. Sabendo-se que naquela época o Atlântico ainda não havia sido aberto, os citados autores formularam a hipótese de que a invasão teria procedido do Oeste, alimentada pelo oceano Panthalassa. Presume-se que tal ingressão invadiu as áreas planas pré-andinas na costa oeste do Gondwana, espraiando-se para leste, por sobre a bacia do Chaco e provavelmente sobre partes marginais da Bacia do Paraná. Nesta trilha ocorrem também importantes seqüências cretácicas continentais, como as da Bacia dos Parecis, no Estado de Mato Grosso. A se considerar tal ingressão marinha, dois pontos importantes permanecem: (a) como conciliar a paleobatimetria encontrada através de dados paleontológicos, com os dados geológicos que indicam sedimentação em água rasa e; (b) como estabelecer um cenário paleogeográfico coerente considerando que, entre a Bacia Sanfranciscana e a suposta área fonte da ingressão marinha existia uma barreira orográfica de grande porte (AAP), a qual constituía um obstáculo natural ao avanço dessas águas mais para leste, além da Bacia do Paraná.

(b) Dardenne et al. (1990) e Campos et al. (1992) reconheceram como sendo de origem glacial uma seqüência de arenitos, paraconglomerados e siltitos que ocorrem no noroeste mineiro, denominando-a de Grupo Santa Fé e atribuido-lhe uma idade permo-carbonífera. A glaciação foi a responsável pela paleogeomorfologia local, cujos vales, esculpidos pelas geleiras em arcósios do Grupo Bambuí, foram preenchidos por conglomerados, correlacionados por Campos e Dardenne (1994) aos sedimentos cretáceos basais da Bacia Sanfranciscana. Deste modo vastas extensões de ruditos anteriormente atribuídos ao Terciário foram então reconhecidos como cretácicos.

Outro fator com implicações econômicas e geotectônicas é o fato de que os citados sedimentos basais da Bacia Sanfranciscana conterem diamantes (Hasui \& Penalva (1970). Sua origem foi atribuída à incorporação dos diamantes aos conglomerados cretácicos pelo retrabalhamento dos tilitos subjacentes, os quais teriam atuado como agentes concentradores de tais gemas oriundas de longas distâncias (Tompkins \& Gonzaga 1989). Tal hipótese descarta uma origem para os diamantes a partir dos kimberlitos cretácicos do Alto Paranaíba, sendo a solução deste problema de fundamental importância ao aprofundamento do conhecimento geológico regional.

(c) Carvalho et al. (1995) descreveram pioneiramente a ocorrência de peixes celacantídeos do gênero Mawzonia em sedimentos lacustres do Grupo Areado, também no Noroeste do Estado de Minas Gerais. Trata-se de um peixe gigante de água doce, típico do Aptiano continental do Gondwana (Wenz 1970, 1980,1981; Carvalho 1982; Ameida-Campos 1982). Representa a terceira ocorrência no País -depois da Chapada do Araripe e Bacia do Recôncavo-, existindo mais quatro outras em sedimentos continentais do Niger e Marrocos, na África. O achado reveste-se de grande importância por estender a ocorrência desses Celacantos à latitudes médias, além de contribuir ao conhecimento da paleogeografia e identidade faunal do Gondwana Central, no Aptiano.

O presente estudo relaciona-se com a parte meridional da bacia, nas imediações do Arco do Alto Paranaíba. Neste local ocorre uma variada seqüência continental totalizando, segundo perfís estratigráficos integrados, cerca de 500 metros de sedimentos e lavas. A deposição iniciou-se no Juro-Cretáceo, ou Cretáceo Inferior, em episódio relacionado com a Reativação Wealdeniana (Almeida 1967a), um episódio tectônico 
que afetou a maior parte da então estável Plataforma brasileira. Esforços compensatórios relacionados ao aporte das lavas Serra Geral da Bacia do Paraná teriam gerado as condições para a formação da depressão do lado oposto ao AAP, que recebeu o início da sedimentação na Bacia Sanfranciscana.

$\mathrm{O}$ advento dessa bacia relaciona-se portanto com os efeitos iniciais contemporâneos aos primeiros esforços da abertura do Atlântico Sul. Este embaciamento inicial foi denominado Depressão do Abaeté (Hasui et al. 1975; Hasui \& Haralyi 1991). Cabe ressaltar que o arcabouço tectônico da bacia ainda não foi inteiramente definido e extensas áreas permanecem ainda sem estudos específicos, notadamente em sua parte norte.

A Bacia Sanfranciscana, na região estudada, consiste dos grupos Areado (Cretáceo Inferior) e Mata da Corda (Cretáceo Superior). O primeiro assenta-se, segundo uma discordância erosiva e angular de âmbito regional, sobre metapelitos do Grupo Bambuí (Grossi Sad et al. 1971, Ladeira \& Brito 1968). Constitue-se pela Formação Abaeté, seqüência basal da bacia, sendo formado por conglomerados matriz-suportados exibindo ventifactos e outras feições de clima desértico como argilas infiltradas mecanicamente, cimentação por carbonato de cálcio e tingimento de clastos por vernizes, notadamente manganês (Sgarbi 1989). Foi formado por detritos originários das terras altas do AAP situado a oeste (Fig.6A), (Sgarbi \& Ladeira 1995a), tendo sido depositado por lençóis de escoamento formando leques aluviais, depósitos fluvio-torrenciais do tipo wadi e, localmente, por suspensão e tração, quando os fluxos de detritos alcançaram corpos lacustres situados nas áreas deprimidas do relevo formando pequenos corpos turbidíticos. Tais depósitos indicam a reativação da erosão por mudança do nível de base devido à tectônica regional, com a conseqüente captura e/ou reativação da rede de escoamento. Mostra sentido de transporte para o norte e nordeste, verificado por embricamento de clastos e estratificações cruzadas nas areias associadas.

Segue-se uma seqüência lacustre do tipo playa lake, com amplo espalhamento geográfico, alongada na direção N-S. Constitue-se por folhelhos, arenitos e lentes de calcários (Sgarbi 1991a, Sgarbi et al. 1993). Mostram feições como pseudomorfos calcificados de cristais de gipso, moldes de cubos de sal e travertinos fossilizados (Moraes et al. 1986, Sgarbi 1989). Dados isotópicos de $\mathrm{C}$ e $\mathrm{O}$ mostraram que o lago era do tipo evaporítico com decréscimo da salinidade em direção ao topo da seqüência (Sgarbi et al. 1993).

A seqüência lacustre exibe remanescente fósseis como os citados Celacantos (Carvalho et al. 1995), além de outros peixes osteoglossiformes dos gêneros Dastilbe (Scorza \& Santos 1955) e Laeliichthys Ancestralis (Santos 1985), este último relacionado com formas recentes de outras partes da América do Sul, África, Austrália e Índia, cujas origens se remetem ao Aptiano do Gondwana. Os folhelhos exibem ainda uma assembléia polinística (Transitoripollis crisopolensis) do Eoaptiano (Lima 1979, Arai et al. 1995), além de ostracodes de água doce dos gêneros Darwinula e Cypridea, diagnósticos do Aptiano, juntamente com Ilyocypris e Pattersoncypris(?) (Arai et al. 1995). O topo da seqüência lacustre mostra intensa deformação mecânica por recalque diferencial devido ao aporte dos arenitos fluvio-deltáicos superpostos. A Formação Três Barras representa a seqüência superior do Grupo Areado, sendo constituída por um um pacote arenoso transgressivo de origem fluvio-deltáica e eólica que cobriu e extravasou os limites dos litossomas precedentes. Com depocentro situado a sudeste de Patos de Minas (Fig.5), mostram aspectos químicos e diagenéticos típicos de sequências do tipo red beds: películas de hidroxidos-óxidos de ferro envolvendo grãos detríticos arenosos, formação de pseudo-matriz, argilas mecanicamente infiltradas e intensa cimentação polifásica por K-feldspatos autigênicos, silica e carbonato de cálcio (Sgarbi 1989, Sgarbi 1991b, De Ros et al. 1994, Sgarbi \& De Ros 1995b). O nível marinho descrito por Kattah (1991) intercala-se em arenitos eólicos desta Formação. O topo da seqüência mostra uma discordância erosiva observada apenas no âmbito da bacia (Braun 1970, Sgarbi 1992), já mostrando indícios do vulcanismo- deformação mecânica pelo aporte de lavas e incorporação à areias eólicas de clastos vulcânicos - fato que vem comprovar a contemporaneidade existente entre o final da deposição Areado e o início do vulcanismo Mata da Corda (Fig. 6A).

O Grupo Mata da Corda, superposto, contitue-se nesta parte da bacia pelas formações Patos e Capacete. A primeira consiste em um dos mais notáveis exemplos de vulcanismo ultramáfico intracontinental de filiação alcalina do Mesozóico. Sua natureza, ambiência tectônica, relações de campo, assim como suas características petrográficas e químicas somente agora começam a serem compreendidas. Um entrave ao seu estudo é a sua grande susceptibilidade à alteração química, apresentando-se normalmente decomposta. Constitue-se por rochas alcalinas, potássicas a ultrapotássicas, vinculadas espacial e temporalmente com kimberlitos e lamproítos que ocorrem regionalmente (Moraes et al. 1987, Danni \& Scartezini 1990, Sgarbi 1991c). Foram datadas por Hasui \& Cordani (1968) em 80-87 M.a. (K/Ar), sendo tais dados compatíveis com os mais recentes $\left(\mathrm{Ar}^{40} / \mathrm{Ar}^{39}\right)$ obtidos por Gibson et al. (1995). Química e petrograficamente relacionam-se com os kamafugitos africanos de ToroAnkole (Danni \& Scartezini 1990, Sgarbi 1991c, Sgarbi \& Valença 1991,1993).

Importantes também no contexto do vulcanismo regional que afetou a região Oeste do Estado de Minas Gerais são as intrusões alcalinas do Cretáceo Superior de Tapira, Araxá, Salitre e Serra Negra (MG), Catalão I e Catalão II (GO), periféricas ou semi-periféricas às bacias do Paraná e Sanfranciscana (Ulbrich \& Gomes 1981, Almeida \& Carneiro 1989). Adicionalmente, ocorrem a Sul e Sudeste, rochas alcalinas de Tinguá e 
Cabo Frio, Poços de Caldas e Itatiaia, estas sendo representantes dos últimos eventos vulcânicos já no limiar do Cretáceo Superior, inicio do Terciário.

A Formação Capacete, superposta, reflete principalmente a retomada da reativação tectônica no AAP no Cretáceo Superior e o subseqüente episódio erosivo que afetou as lavas da Formação Mata da Corda. A formação consiste de conglomerados e arenitos, epiclásticos, com intercalações de lavas e material piroclástico. Foram depositados principalmente por lençóis de escoamento formando leques aluviais, associados a torrentes fluviais mostrando transporte para norte e nordeste. Assim como ocorre com a Formação Uberaba do Grupo Bauru do qual é cronolito-correlata, os termos psefíticos dominam nas imediações do AAP, com os psamitos propagando-se para leste (Fig. 6B) na medida em que se afastam do arco. Tais arenitos e conglomerados constituem, juntamente com os termos magmáticos, os platôs de topo plano e contornos festonados característicos da bacia, apresentando comumente alto grau de oxidação. O final do Cretáceo na Bacia do São Francisco mostra o término da sedimentação e o arrefecimento do vulcanismo alcalino. Segue-se um amplo soerguimento regional que elevou os litossomas do topo da bacia à cotas situadas entre 1000 e 1200 metros como atesta o Planalto da Mata da Corda, importante feição orográfica regional.

O topo plano desse planalto representa a superfície de erosão Sul Americana, que mostra solos arenosos profundamente laterizados e lixiviados, com estruturas relícticas de clastos vulcânicos. Representam apenas fração da sedimentação original, conforme sugerem as bordas do Planalto profundamente escavadas pela erosão formando amplos anfiteatros, assim como inúmeros morros testemunhos cretácicos, isolados sobre o substrato proterozóico.

A região enfocada, a qual engloba o Arco do Alto Paranaíba, a parte meridional da Bacia Sanfranciscana e a parte nordeste da Bacia do Paraná, constitue uma das mais importantes províncias diamantíferas do País (Hasui \& Penalva 1970). Diamantes são encontrados em aluviões recentes e muitas drenagens originam-se de áreas nas quais ocorrem a Formação Capacete, no Planalto da Mata da Corda (p.e. os rios Abaeté na Bacia Sanfranciscana e o Rio Paranaíba, na Bacia do Paraná). Entretanto, não se tem até o momento nenhuma correlação segura entre esta mineralização e os referidos conglomerados vulcânicos.

A Bacia Sanfranciscana e o substrato paleozóico da Bacia do Paraná são correlatos com alguns depósitos na África. As seqüências do Paleozóico SuperiorMesozóico Inferior da Bacia do Karroo que ocorrem na África Meridional são similares às rochas de mesma idade da Bacia do Paraná. Nas partes oeste e central do continente africano -Angola, Zaire e Republica Centro Africana- ocorrem seqüências sedimentares cronocorrelatas às da Bacia Sanfranciscana (Baty 1948, Lepersonne 1951). De acordo com Chaves (1991), temse a seguinte correlação entre os sedimentos africanos e os da Bacia Sanfranciscana:

(a) Sistema Continental Intercalar (Angola) e Série Lualaba (Zaire,Congo), do Cretáceo Inferior, de idade pré-vulcanismo alcalino. São formados por sedimentos de origem fluvial e lacustre, sendo correlatos ao Grupo Areado da Bacia Sanfranciscana;

(b) Formação Calonda, Série Luanda (Angola) e Serie Kwango (Angola, Congo e República Centro Africana), de idade pós-vulcanismo alcalino, são formadas por conglomerados basais originárias por leques aluviais, contendo diamantes, além de depósitos eólicos e flúvio-lacustres. São correlatas à Formação Capacete do Grupo Mata da Corda, Bacia Sanfranciscana e à Formação Uberaba da Bacia do Paraná.

Estes depósitos marcam a continuidade paleoclimática do Cretáceo no Gondwana, em época pré e pós fragmentação dos continentes africano e americano do sul.

\section{A BACIA DOS PARECIS}

A Bacia dos Parecis, situada no Estado do Mato Grosso (Fig.4), tem merecido poucos estudos. Petri \& Fulfaro (1981) descreveram como sendo o substrato da bacia os basaltos da Formação Tapirapuã e os sedimentos Pré-silurianos do Grupo Alto Paraguai. Associaram esses basaltos aos derrames cretácicos do Grupo São Bento da Bacia do Paraná, descrevendo para os mesmos uma área de ocorrência de $350 \mathrm{Km}^{2}$ e uma espessura máxima de 300 metros. Atribuíram à seqüência sedimentar cretácica pós-magmática Formação Parecis (Oliveira \& Leonardos 1943)- uma idade cretácica superior, descrevendo-a como sendo formada por siltitos e arenitos finos na base e conglomerados no topo, ambos de origem fluvial. Entretanto, Vieira (1965) e Correa \& Couto (1972) apud Petri \& Fulfaro (1981) atribuiram uma origem eólica aos arenitos basais da Formação Parecis. Não se pode descartar entretanto a possibilidade destes autores terem incorporado à bacia dos Parecis, arenitos eólicos da Formação Botucatú que localmente ocorrem na região (Weska et al. 1996).

Restos reptilianos nessa bacia foram descritos por Roxo (1937 apud Weska et al. 1996), assim como troncos silicificados de idade indefinida (Oliveira 1936). Trabalhos mais recentes têm modificado alguns conceitos relativos à Bacia dos Parecis. Dados radiométricos concernentes aos basaltos Tapirapuã mostraram que os mesmos originaram-se de evento distinto daquele relacionado ao vulcanismo do Grupo São Bento, tendo fornecido idade $\mathrm{Ar}^{40} / \mathrm{Ar}^{39}$ de 197 M.a., posicionando-se, portanto, no Jurássico Inferior (Montes-Lauar et al. 1994). A ocorrência de um substrato mais antigo que o previamente suposto, sem que se tenham verificado registros de longas interrupções no registro geológico entre este embasamento e a sequência sedimentar cretácica superposta, permite supor a presença, na bacia, de sedimentos cretácicos mais antigos que o Cretáceo Superior. 


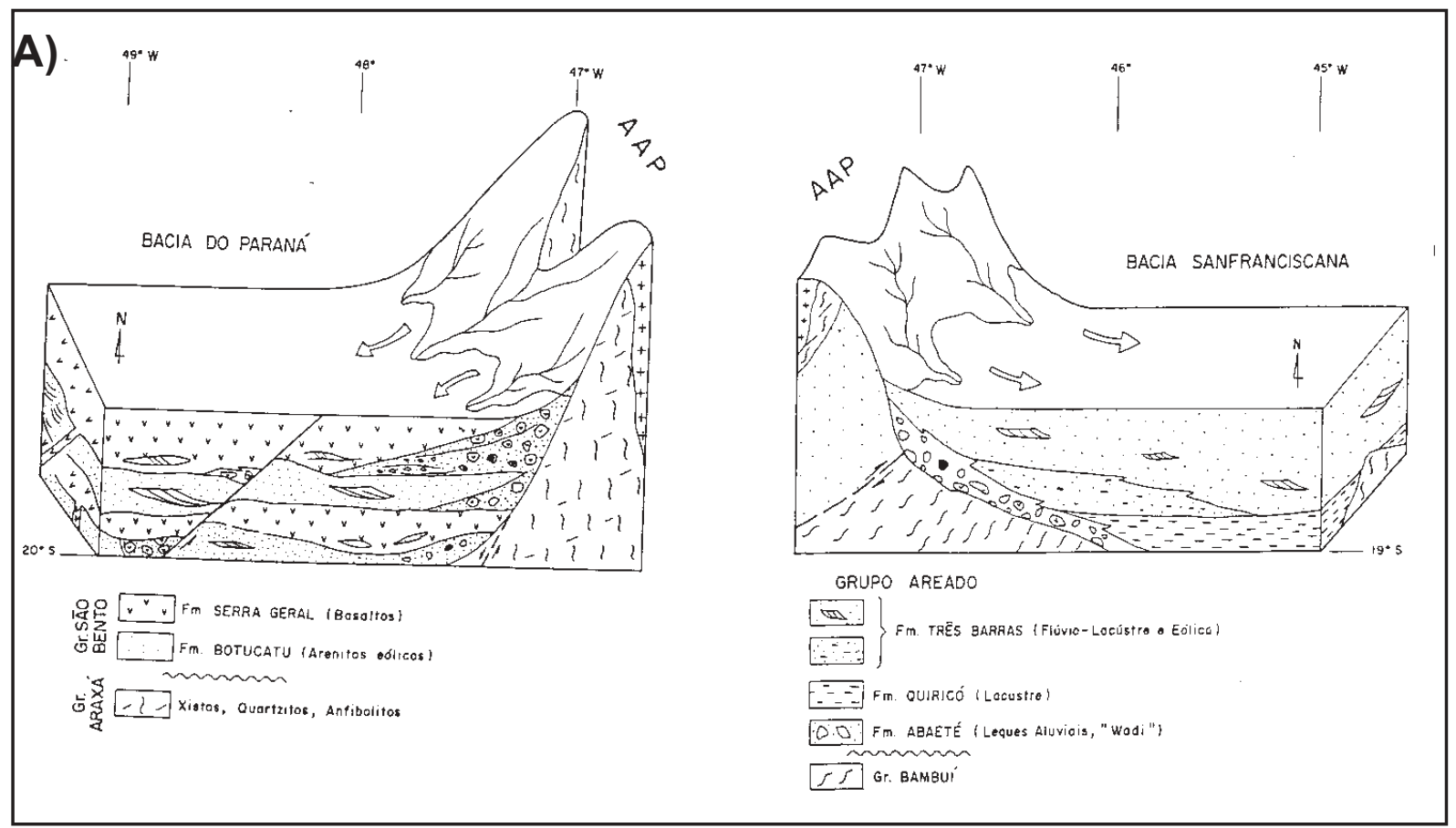

B)<smiles>[3H]</smiles>
JACIA DO PARANÁ

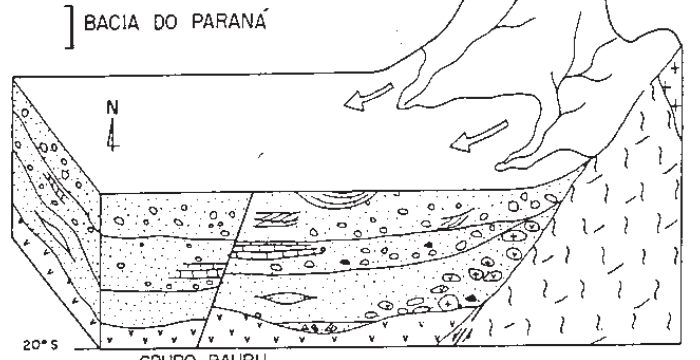
GRUPO BAURU

DE:

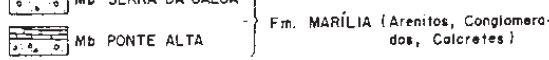

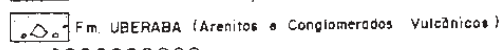

GRUPO SÄO BENTO

" Fm. SERRA Geral tongaltos?
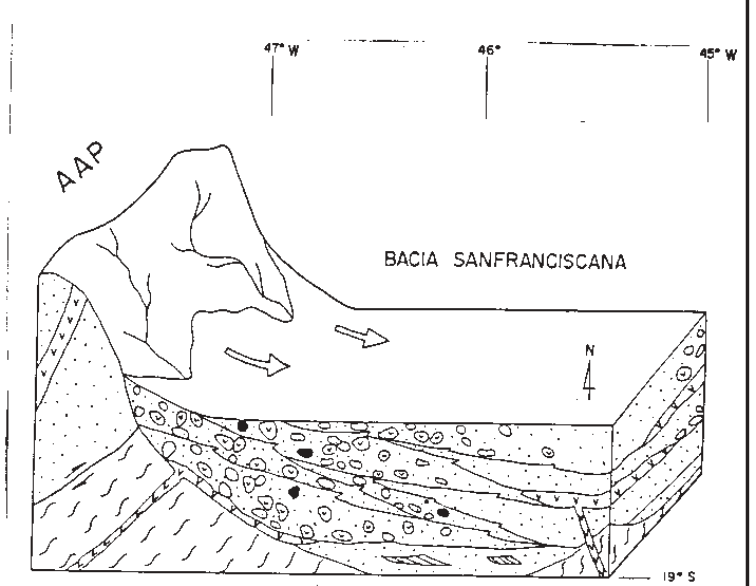

GRUPO MATA DA CORDA

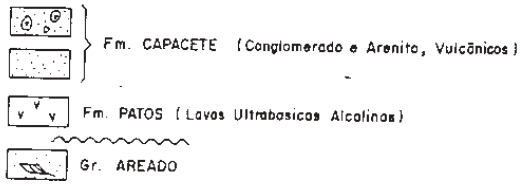

Figura 6: Reconstrução paleogeográfica do Cretáceo Inferior(A) e Cretáceo Superior (B) envolvendo o Arco do Alto Paranaíba (AAP), a borda NNE da Bacia do Paraná e a porção meridional da Bacia Sanfranciscana. O cenário mostra o comportamento do AAP como importante área fonte clástica para ambas as bacias durante todo o Cretáceo.

Figure 6: Early Cretaceous (A) and Late Cretaceous (B) paleogeographic models in the west of Minas Gerais State, showing the relationhip between the Alto do Paranaiba Arch (AAP) and the Parana and Sanfranciscana basins. The scenery shows the AAP as an important source area for these marginal basins during the Cretaceous. 
A Bacia dos Parecis mostra, também, ocorrências de sequências bastante diversas das descritas anteriormente por Petri \& Fulfaro (1981), não se sabendo ao certo se o fato deve-se à retirada local de partes da sedimentação por atuação de fenômenos erosivos ou pela existência de variações faciológicas na bacia. Por exemplo, Weska et al. $(1988,1996)$, estudaram seqüências cretácicas em uma área situada a sudeste daquela estudada por Petri \& Fulfaro (1981). Neste local ocorrem pacotes individuais, geograficamente isolados de sedimentos vulcanoclásticos formando leques aluviais, exibindo intercalações magmáticas. Pela geometria dos corpos, parecem representar remanescentes erosivos de uma bacia maior, tectonicamente desenvolvida em echelon ao longo do eixo do rift Rio das Mortes (Gibson et al. 1996). As bacias são bem expostas ao longo da Chapada dos Guimarães e Poxoreu, ocorrendo também nas áreas de Cambambe, Rio das Mortes e outras (Weska 1996, informação pessoal).

Neste novo local a seqüência inicia-se por basaltos alcalinos do tipo OIB, cujas determinações radiométricas $\mathrm{Ar}^{40} / \mathrm{Ar}^{39}$ forneceram idade de cerca de 84 M.a. (Gibson et al. 1996). Tal fato indica que os mesmos não possuem ligação crono-litológica nem com os basaltos Serra Geral nem com aqueles da Formação Tapirapuã. Associam-se diques e um complexo sienitomonzonito-granito. Superpostos aos basaltos ocorre uma seqüência de conglomerados e arenitos, epiclásticos, com espessura total de 360 metros, exibindo intercalações de traquiandesitos, piroclastos e olivina-basaltos. Intensa cimentação carbonática, inclusive com a formação de calcretes, ocorreu na parte média da seção.

Em direção ao topo, os conglomerados são substituidos gradualmente por arenitos, diminuindo o conteúdo em clastos de rochas vulcânicas. O pacote foi interpretado como sendo resultante de variações de um amplo regime de leques aluviais, gradando de proximal na base para distal no topo. Weska et al. (1996) indicaram para essas ocorrências uma origem vulcano-clasto-química do tipo "rift" e as correlacionaram ao Grupo Bauru. Tais sedimentos são também geográficamente isolados da Bacia do Paraná. O Alto de Rondonópolis delimita, a sudeste, este conjunto de sedimentos cretácicos Parecis daqueles tradicionalmente referidos ao Grupo Bauru da Bacia do Paraná (Fig. 5).

\section{CONCLUSÕES}

Com o término do Paleozóico, época em que imperavam condições climáticas amenas no Gondwana Centro-Sul e o subseqüente advento do Mesozóico, as terras do Gondwana assistiram à instalação do maior episódio de desertificação já registrado. A modificação climática, considerada a mais drástica da história do Planeta proporcionou o maior episódio de extinção biológica já registrado. É consenso a idéia de que variações climáticas globais como a enfocada, ocorridas ao longo do tempo geológico são atribuídas à variação no teor de gases presentes na atmosfera, notadamente o $\mathrm{CO}_{2}$. As causas do aporte destes gases entretanto, não são consensuais e as hipóteses discutidas no texto são sobre (a) vulcanismo em larga escala, (b) choque por objeto extraterrestre e (c) efeito regulador controlado pelos organismos.

Como consequência da instalação desse megasistema desértico por uma extensão de milhões de quilômetros quadrados da parte centro-sul do Gondwana, implantou-se, desde o início do Triássico, a deposição de sedimentos continentais do tipo red beds, conforme atestam o Grupo Rosário do Sul e a Formação Pirambóia, que ocorrem a partir da parte meridional do País. Posteriormente, no Jurássico, ocorreu um expressivo período de exposição contínua da plataforma brasileira a severos processos erosionais, nesta parte do Gondwana. Grande parte da sedimentação triássica possivelmente se perdeu, igualmente com amplas porções dos sedimentos do topo da Bacia do Paraná e do substrato mais antigo a ela circundante. Não se tem registros de sedimentação continental deste período na área enfocada, exceto no final do período, com a implantação do Deserto Botucatu. Aparecem entretanto, na literatura, estudos pouco embasados, posicionando de modo discutível a Formação Botucatu no Jurássico Inferior-Médio.

No Cretáceo, esforços intraplaca que o precederam o rifteamento que originaria o Atlântico Sul, modificaram o relevo da antiga e estável plataforma jurássica. Criaram-se então as condições morfotectônicas e climáticas necessárias à deposição e preservação das seqúências cretácicas, como as lavas e arenitos do Grupo São Bento ( Formação Botucatu e Formação Serra Geral) e o Grupo Bauru na Bacia do Paraná, os grupos Areado e Mata da Corda na Bacia Sanfranciscana e a Formação Parecis na bacia homônima, no Estado do Mato Grosso. Estas bacias cretácicas foram escolhidas como modelo para uma apresentação paleogeográfica e paleoclimática do Cretáceo no Gondwana Centro-Sul, permitindo as seguintes correlações:

(a) A sedimentação levada a efeito no ValanginianoHauteriviano/Barremiano Inferior (Cretáco Inferior) sugere a existência de clima desértico, com base nas evidências mostradas pela Formação Botucatu da Bacia do Paraná e pelos sedimentos basais do Grupo Areado da Bacia Sanfranciscana. Ambas mostram amplo espalhamento de depósitos de dunas eólicas associadas com sedimentos de leques aluviais, além da ocorrência de ventifactos, níveis de argilas mecanicamente infiltradas e extensa cimentação por sílica na Bacia do Paraná e por sílica e carbonato na Bacia Sanfranciscana. Uma possibilidade é o fato de tais sedimentos se correlacionarem, temporalmente, com aqueles com aqueles da Formação Parecis da Bacia homônima, descritos por Petri \& Fulfaro (1981);

(b) A época subseqüente representada pelo Aptiano 
Inferior, no interior do Gondwana central favoreu a instalação de climas mais amenos. Extensos depósitos lacustres do Grupo Areado implantaram-se a partir da borda oriental do Arco do Alto Paranaíba, na Bacia Sanfranciscana. Ocorrências de sedimentos lacustres, que localmente chegam a atingir cerca de 100 metros de espessura, podem ser observados desde a sul da latitude $19^{\circ} \mathrm{S}$ até a norte da latitude $17^{\circ} \mathrm{S}$, em uma extensão de mais de 200 quilômetros no sentido N-S.

Apesar de se tratar de um lago evaporítico com episódios de retração aquosa, sua própria existência indicava um período de maior aporte de umidade à região.

O ambiente era entretanto desértico, possivelmente semi-árido, fato evidenciado pelas dunas eólicas que bordejavam e localmente se instalavam-se sobre as seqüências marginais do lago. A evolução geológica na região mostra o assoreamento do lago por corpos flúvio-deltaicos e eólicos do mesmo Grupo Areado Formação Três Barras, possível equivalente da Formação Botucatu), provavelmente no Albiano, indicando uma retomada das condições mais áridas no período. A época coincide com a instalação do deserto Caiuá, na Bacia do Paraná, o qual corresponde ao intervalo Albiano-Cenomaniano e com a ainda pouco compreendida ingressão marinha sanfranciscana, proposta por Kattah (1991);

(c) No Turoniano-Coniaciano irrompeu o vulcanismo alcalino Mata da Corda, nas regiões da Bacia Sanfranciscana e Arco do Alto Paranaíba, que se prolongou até pelo menos o Campaniano. Formação de relevo, associado ao vulcanismo, sincrônicos com a instalação de períodos mais úmidos proporcionaram o cenário típico da época na Bacia Sanfranciscana conforme atestam os registros geológicos como intercalações de sedimentos epiclásticos originários de leques aluviais e torrentes fluviais com derrames vulcânicos e sedimentos piroclásticos da Formação Capacete. Esta seqüência sedimentar pós-magmatismo alcalino do Cretáceo Superior é correlacionada à Formação Uberaba e Adamantina do Grupo Bauru da Bacia do Paraná. Indica um período de retomada das condições úmidas ao ambiente, o qual suportou a explosão de vida na Bacia do Paraná, cujos remanescentes fósseis se encontram, na porção NNE da bacia, encerrados na Formação Marília como material alóctone. Muito provavelmente essa seqüência sedimentar vulcânica se correlaciona com aquela descrita por Weska et al. (1996) na Bacia dos Parecis. De acordo com Hasui \& Haralyi (1991), o cenário sugere, para ambas as depressões marginais ao AAP, uma origem relacionada com pluma do manto associada a processo de rifteamento que teria afetado o AAP. O rifte não evoluiu para o estágio oceânico, encerrando sua atividade ainda no Cretáceo. Essa interpretação não é entretanto conclusiva face a não existência de feições tectônicas associadas a rifteamento, como por exemplo, extensão litosférica com a formação de grabens.

(d) O Maastrichtiano mostra a retomada de um novo período árido na região. Sedimentos de borda de escarpa relacionados a leques aluviais da Formação Marília coroam o Grupo Bauru na borda NNE da Bacia do Paraná. Ocorrem como conglomerados polimícticos e arenitos impuros, exibindo intensa cimentação carbonática e silicosa. $\mathrm{O}$ alto grau de aridez, talvez o maior observado em toda a seqüência cretácica ora estudada, pode ser deduzido pelos extensos, volumosos e únicos depósitos de calcretes que ocorrem na região. $\mathrm{Na}$ Bacia Sanfranciscana não se observa a ocorrência de depósitos crono-correlatos, fato que provavelmente relaciona-se à orogênese pós-cretácica que elevou acima do nível de base regional os litossomas do topo da Bacia Sanfranciscana, observados atualmente em cotas de 1000-1200 metros de altitude.

\section{AGRADECIMENTOS}

Os autores agradecem ao Prof. Dr. Paulo P.Martins Jr. (Degeo-UFOP), que gentilmente realizou a leitura crítica do texto, incorporando valiosas sugestões e correções. Os recursos foram supridos pela FAPEMIG (processo CEX 1117-93) e CNPq (processo 400419/94.7).

\section{REFERÊNCIAS BIBLIOGRÁFICAS}

AGUIAR, G.A. 1971. Revisão geológica da Bacia Paleozóica do Maranhão. IN: CONGR.BRAS.GEOL., 25, São Paulo, 1971. Anais...,SBG, São Paulo, vol.3, pl 113-122.

ALBERTÃO, G.A., KOUTSOUKOS, E.A.M., REGALI, M.S.P., ATTREP Jr.M.; MARTINS Jr., P.P., 1992. The CretaceousTertiary boundary events and its record in Brasilian sedimentary basins. Acta Geol.Leolpodensia, v. XV, n.39, p.163-165.

ALBERTÃO,G.A. \& MARTINS Jr.,P.P.,1996. -A possible tsunami deposit at the Cretaceous-Tertiary boundary in Pernambuco, northeastern Brazil. Sedimentary Geology, 104:189-201.

ALBERTÃO,G.A.;KOUTSOUKOS,E.A.M.;REGALI,M.S.P.; ATTREP Jr.M.; MARTINS Jr P.P., 1994. The CretaceousTertiary boundary in southern low-latitude regions: preliminary study in Pernambuco, northeastern Brazil. Terra Nova 6:366:375

ALMEIDA, F.M. de, 1954. Botucatu, um deserto triássico da América do Sul.Rio de Janeiro, DNPM, Div.Geol.Min., Notas Prelim. e Estudos 86, 21 p.

ALMEIDA, F.M. de, 1967a. Origem e evolução da plataforma brasileira. Rio de Janeiro, DNPM, Div.Geol.Min., Bol. 241, $36 \mathrm{p}$.

ALMEIDA,F.F.de \& BARBOSA,O.,1953.Geologia das quadrículas de Piracicaba e Rio Claro, Estado de São Paulo. Bol. 143 Div.Min.Petr., Rio de Janeiro, 96 p.

ALMEIDA,F.F.de \& CARNEIRO,C.D.R.,1989. Magmatic occurrences of Post-Permian age of South America Plattform. Bol IG-USP, Sér.Cient.,20:71-85.

ALMEIDA,F.M.de, 1967b. Observações sobre o Pré-Cambriano na região central de Goiás. 210.Congr.bras.Geol., Curitiba, Bol.Paranaense de Geociências, (26): 19-22.

ALMEIDA-CAMPOS,D.de \& WENZ,S.,1982. Première découverte de Coelacanthes dans le Crétacé Inférieur de la Chapada du Araripe (Brésil). C.R.Acad.Sc.Paris, t. 294, Série II, p. 11511154.

ALVAREZ, L., ALVAREZ, W., ASARO, G. \& MiCHEL, H.V., 1980. Extraterrestrial cause for the Cretaceous-Tertiary extinction. Science, 208:1095-108.

ALVAREZ,W. \& ASARO,F.,1990. An extraterrestrial impact. Sci.Amer., 263(4):44-52.

AMARAL, G., CORDANI, U.G., KAWASHITA, K. \& REYNOLDS, J.H., 1966. Potassium-argon dates of basaltic rocks from Southern Brazil. Geochim. et Cosmochim. Acta, 
Oxford, 30(2):159-189.

ANDREIS, R.R.,BOSSI,G.E.,MONTARDO,D.K.,1980. O Grupo Rosário do Sul (Triássico) do Rio Grande do Sul. XXXI Congr.bras.Geol.2:659-73.

ARAI,M.;DINO, R.; MILHOMEM, P.S.; SGARBI, G.N.C.; 1995. Micropaleontologia da Formação Areado, Cretáceo da Bacia Sanfranciscana: estudos de ostracodes e palinologia. In: 34o.Congr.bras.Paleontologia, Uberaba, p. 2-3

ASMUS,H.E. \& PORTO, R., 1972. Classificação das bacias sedimentares brasileiras segundo a Tectônica de Placas. IN: CONGR.BRAS.GEOL. 26, Belém, 1972.Anais... Belém, SBG, v. 1, p.67-90.

BAKSI,A.K.;FODOR,R.U.;FARRAR,E.,1991. Preliminary results of $\mathrm{Ar} / \mathrm{Ar}$ dating on rocks from the Serra Geral flood-basalts Province and Brazilian continental margin. Eos-AGU program with abstracts, 300 .

BARBERENA,M.C.,1977. Bioestratigrafia preliminar da Formação Santa Maria. Pesquisas, 7:111-129.

BARBOSA, E.M. \& CASTRO, P. de T. A., 1992. Ocorrências de ventifactos em rochas da Formação Marília, Grupo Bauru, Cretáceo da Bacia do Paraná em Minas Gerais. Acta Geológica Leopoldensia 36. vol. XV, p.152-153.

BARBOSA,O;BRAUN,O.P.G.;DYER,R.C.;CUNHA,C.A.B.R.; 1970. Geologia da região do Triângulo Mineiro. Bol.136 do DNPM, Rio de Janeiro, 140 p.

BARCELOS, J.H., 1989. Influência do soerguimento do Alto Paranaíba na sedimentação pós-basáltica na área do Triângulo Mineiro (MG), borda NNE da Bacia do Paraná. São Paulo, Geociências, 8:37-54

BARCELOS, J.H., SUGUIO, K., GODOY, A.M., HIRATA, R.A. \& GONTIJO, R.C., 1987. Aspectos litoestratigráficos da Formação Uberaba, Cretáceo da Bacia do Paraná. Geociências, $5 / 6: 31-42$.

BARCELOS, J.H.,, LANDIN, P.M.B., SUGUIO, K., 1981. Análises estratigráficas das seqüências cretácicas no Triângulo Mineiro e suas correlações com as do Estado de São Paulo. III Simp. Reg.Geol, Curitiba, v.2, p. 90-102.

BASU, A.R.; RENNE, P.R.; DAS GUPTA, D.K.; TEICHMANN, F.; POREDA, R.J., 1993. Late an early alkali pulses and a high -3 He plume origin for the Deccan flood basalts. Science, 261:902-905.

BATY,V.,1948. Contribution à l'étude des formations du Karroo e du Kalahari au Kwango méridional (Congo Belge). Des formations diamantières. Ann.Soc.Géol.de Belgique. T. 71, p. 23-31.

BELLIENI G., COMIN-CHIARAMONTI, P., MARQUES, L.S., MELFI, A.J., PICCIRILLO, E.M., NARDY, A.J.R., ROISENBERG,A., 1984. High- and -low Ti flood basalts from the Parana Plateau (Brazil). Petrology and geochemical aspects bearin in the mantle origin. N Jb Miner. Abh, 150:273-306.

BENTON,M.J.,1986. More than one event in the late Triassic mass extinction. Nature, 321(6073):857-861.

BERTINI, R.J., 1996b. Cintura pélvica de Baurusuchus Pachecoi Price, 1945, em sedimentos da Formação Adamantina (Grupo Bauru), Cretáceo Superior). Bol.IV Simp. sobre o Cretáceo do Brasil, Unesp, Rio Claro, p. 273-276.

BERTINI,R.J., 1996a. Evidências de Abelisauridae (Carnosaura:Saurischia) do Neocretáceo da Bacia do Paraná. Bol.IV Simp. sobre o Cretáceo do Brasil, Unesp, Rio Claro, p. 267-271.

BIGARELLA J.J. \& SALAMUNI R., 1961. Early Mesozoic wind pattern as suggested by dune bedding in the Botucatu sandstones of Brazil and Uruguay. Geol. Soc.America Bull. 72: 1089-1106

BIGARELLA, J.J., 1949. Contribuição à petrologia dos arenitos da Série São Bento. Inst.Biol. Pesq.Tecnol., vol.IV, p.141-214.

BIZZI, L.A., 1993. Mesozoic alkaline volcanism and mantle evolution of southwestern Sao Francisco Craton, Brazil. (PhD. Thesis), Univ. Cape town, South Africa, 240 p.

BOURGEOIS, J.,HANSEN, T. A., WIBERG, P.L.\& KAUFFMAN, E.G., 1988. A Tsunami deposits at the Cretaceous-Tertiary bondary in Texas.Science, 241:567-570.

BRAUN.O.P.G.,1970. A Formação Areado e a Formação Serra Negra. Rev.Esc.Minas Ouro Preto, 28(3)100-106.

BRITO, I.M. \& ALMEIDA-CAMPOS, D.de, 1982. O Cretáceo no
Brasil. An.Acad.brasil.Ciênc., 54:197-218.

BUDYKO,M.I.\& RONOV,A.B.,1979. Chemical evolution of the atmosphere in the Phanerozoic. Geochemical International, 16:1-9.

CAETANO-CHANG, M.R., WU F.T. \& BRIGHETTI, J.M.P., 1991. Caracterização eólica de arenitos da Formação Pirambóia, proximidade de São Pedro (SP). II Simp.Geol.Sudeste, SBG/ SP-RJ, São Paulo, p.6.

CAETANO-CHANG,M.R.\& WU,F.T.,1994. Afloramento modelo da Formação Pirambóia. Geociências, 13(2):371-385.

CALVO,J.O. \& SALGADO,L.,1996. A land brigde connection between South America and Africa during the AlbianCenomanian times based on sauropod dinosaur evidences. IN South Atlantic Mesozoic Correlations, IGCP Project n. 381, SAMC News No.5, p.13-14.

CAMINOS,R (coord.),1986. Mapa geológico da Argentina, esc.1:5000 000. Comision del Mapa Geológico de America del Sur, Buenos Aires.

CAMPOS, J.E.G.\& DARDENNE, M.A., 1994. O sistema fluvia entrelaçado dos conglomerados e arenitos do Membro Abaeté na região de Canabrava, MG. III Simp. sobre o Cretáceo do Brasil, 185-187.

CAMPOS, J.E.G., DARDENNE, M.A. \& GONZAGA, G.M., 1992. Registros da glaciação permo-carbonífera na região de Canabrava e Santa Fé de Minas, MG REM, Ouro Preto, VI Simp. Geol.de Minas Gerais, vol. 45 p. 109-111.

CARTA GEOLOGICA -REPUBLICA ORIENTAL DEL URUGUAY, 1974. M.M.E.(sem autores descritos), Esc. 1:500 000 .

CARVALHO, M.S.S. de, 1982. O gênero Mawonia na Icthiofáuluna do Cretáceo do Estado da Bahia. An.Acad.bras.Cienc., 54(3):519-539.

CARVALHO, M.S.S. de; ALMEIDA CAMPOS D.de;DARDENNE,M.A.;SGARBI,G.N.C.;CAMPOS, E.G.;CARTELLE,C.;1995. Celacantos do Cretáceo Inferior de Minas Gerais, Brasil. XIV Congr.bras.Paleontologia, Uberaba, p. 35 .

CHAVES, M.L.de S.C., 1991. Seqüências cretácicas e mineralizações diamantíferas no Brasil Central e África CentroMeridional: Considerações Preliminares. Geociências, 10:231245.

CLARK,D.L.;WANG,C.Y.;ORTH,C.J.;GILMORE,J.S.;1986. Conodont survival and the low iridium abundances across the Permian-Triassic boundary in south China. Science, 223:(4767):984-986.

CORDANI, U.G.\& VANDOROS, P., 1967. In Problems in Brazilian Gondwana Geology (eds. BIGARELLA J.J., BECKER, R.D \& PINTO, I.D.), Intern.Symp. of Gondwana Stratigraphy and Paleontology, Univ.Fed.Parana, Brazil, 1967, p.207-301.

COSTA ,M.T.da \& GROSSI SAD, J.H., 1968. O Cretáceo em Minas Gerais. 22o Congr. bras. Geol., Belo Horizonte.

COSTA,M.T.da.;1963. Estrutura geológica dos Cerrados. Dep.Pesq.Experimentos Agropecuários. Ministério da Agricultura, Minas Gerais, Bol. 15.

COTTAS, L.R.,GODOY, A.M., GERALDES, M.C., 1986. Novas considerações petrográficas e estratigráficas sobre as formações Pirambóia e Botucatu da Bacia Sedimentar do Paraná. IN: CONGR.BRAS.GEOL.,34, Goiânia, 1986. Anais...Goiânia, SBG, v.1, p.191-205.

COURTILLOT,V.E.,1990. A volcanic eruption. Sci.Amer.,623(4);53-60

COX, K.G., 1978. Flood basalts, subduction and the break-up of Gondwanaland. Nature 274:47-49.

CREER,K.M., MILLER,J.A., SMITH, A.G., 1965. Radiometric age of the Serra Geral Formation. Nature, 207:282-283.

CRÓSTA,A.P.;GASPAR,J.C.;CANDIA,M.A.F.;1981.Feições de metamorfismo de impacto no Domo de Araguainha. Rev.bras.Geoc., 11(3):139-146.

DANNI, J.C.M.\& SCARTEZINI,A.A.,1990. O olivina lucitito de Pântano e a natureza do vulcanismo da Formação Mata da Corda, MG. Rev.bras.Geoc., 20(1-4):83-87.

DARDENNE, M.A., GONZAGA, G.M. \& CAMPOS, J.E.G., 1990 Descoberta de pavimentos estriados de origem glacial sobre arcósios da Formação Três Marias, na região de Santa Fé de 
Minas, MG. Rev.Esc.Minas de Ouro Preto, 54(4):65-66.

DE ROS, L.F.;SGARBI,G.N.C.;MORAD,S.;1994. Multiple authigenesis of K-feldspar in sandstones: evidence from the Cretaceous Areado Formation, São Francisco Basin, Central Brasil. J.Sedimentary Research, vol A64(4):778-787.

DIAS-BRITO, D.,1995A. Calcisferas e microfácies em rochas carbonáticas pelágicas mesocretácicas. Tese de Doutoramento (UFRS), $433 \mathrm{P}$

DIAS-BRITO,D.,1995b. The South Atlantic Albian carbonates:their Atlantic Albian carbonates:their organogenic content and paleoceanographic significance. IN: I Workshop sobre paleoceanografia com ênfase em micropaleontologia e estratigrafia. Gramado, Ext.Abs., p.47-48.

DIETZ, R.S. \& HOLDEN, J.,1970. The breakup of Pangea. Scientific American, 223(4):30-41.

DIETZ, R.S., (1972). Plate tectonics and continental drift. IN:CONGR.BRAS.GEOL.,26, Belém, 1972. Anais Belém, SBG, v.1,.p.11-17.

DIETZ,R.S.;FRENCH,B.M.;OLIVEIRA,M.A.M.;1973. Araguainha Dome (Goiás) and Serra da Cangalha (MT): a probable astroblemes. 27o.Congr.bras.Geol., Aracaju, Bol.1, p.102-103.

DOSSIN,T.M.;DOSSIN,I.V.;CHARVET,J.;BONHOMME,M.G.; 1995. K/Ar chronology of a Mesozoic dike swarm from southern Espinhaço Region (SE Brazil). J.South Amer.Earth Sci., $8(1): 47-53$

DUNCAN,R.A. \& PYLE,D.G.,1988. Rapid eruption in the Deccan flood basalts at the Cretaceous-Tertiary boundary. Nature, 333:841-843

FACCINI,U.,1989. O Permo-Triássico do Rio Grande do Sul. Uma análise sob o ponto de vista das sequências deposicionais. Dissertação de Mestrado, 2 vol. (mapas), (UFRS), inédita, 133p.

FODOR,R.V.\& VETTER,S.K., 1985. Mineral chemistry and petrography of passive margin basalt, Southeastern Brazil. Rev.Brasil.Geoc., 15(1):36-47.

FRAKES,L.A. (1986). Mesozoic-Cenozoic climatic history and causes of the glaciation. In Mesozoic and Cenozoic Oceans (eds K.J.Hsü, pp.33-48. American Geophysical Union Geodynamics Series no. 15

FRANÇA,A.B., E.J. MILANI, R.L.SCHNEIDER, O.LOPEZ, J.LOPEZ, R.SUAREZ, H.SANTA ANA, F.WIENS, O. FERREIRO, E.A. ROSELLO, et al.,1995. Phanerozoic correlation in southern South America in A.J.TANKARD, R. SUAREZ AND H.J.WELSINK (eds.), Petroleum basins of South America: AAPG Memoir 62, p. 129-161.

FRANZINELLI, E., 1973. Estratigrafia e ambiente de sedimentação do Arenito Pirambóia (Estado de São Paulo). IN CONGR.BRAS.GEOL., 27, Aracaju, 1973. Anais...Aracaju, SBG, p. 229-236.

FUCK,R.A.;PIMENTEL,M.M.;SILVA,L.J.H.D., 1994 Compartimentação tectônica da porção oriental da Província Tocantins (extended abstract). 38o.Congr.bras.Geol., Camboriú, SBH, v.1, p.215-216.

FULFARO,V.J.\& BARCELOS, J.H.,1991. Fase rift na Bacia do Paraná: A Formação Caiuá. III Simp. Nac. de Estudos Tectônicoss, Rio Claro, , 4 p.

FULFARO,V.J.\& PERINOTTO,J.A.J.,1996. A Bacia Bauru:Estado de Arte. IV Simp.sobre o Cretáceo do Brasil. Unesp, Rio Claro, p. 297-303.

FULVARO,V.J.,1970. Contribuição a Geologia da região de Angatuba, Estado de São Paulo. Bol.DNPM,DGM, 253 p.

GALLAGHER, K., HAWKESWORTH, C.J., MANTOVANI, M.S.M., 1995.Denudation,fission track analysis and the longterm evolution of passive margim topography: aplication to the southeast Brazilian margim. J.South Amer.Earth Science, 8(1):65-77

GAMERMANN,N.,1973. Formação Rosário do Sul. Pesquisas, UFRGS, 2:5-16.

GARLAND,F.;TURNER,S.;HAWKESWORTH,C.;KERSTEIN,L:;1994. Major element modelling of changes in lithospheric source with time for the Parana CFB. Goldschmidt Confer.Edinburgh, Mineral.Magaz. v. 58A, p.317-318.

GAYET,M. \& MARQUES-BRITO,P.,1989. Ichtyofaune nouvelle du Crétacé Supérieur du Group Bauru (Etats de São Paulo et Minas Gerais, Brésil). Geobios, 22:841-845.

GIBSON, S. A.; THOMPSON, R.N.; LEONARDOS, O.H.;
MITCHELL, J.G.; 1995. The late Cretaceous impact of the Trindade Mantle Plume: evidence from large-volume, mafic, potassic magmatism in SE Brazil. Journ. Geology 36(1):189229

GIBSON, S. A.; THOMPSON, R. N.; WESKA, R.; DICKIN, A.P.; LEONARDOS,O.H., 1996. Late Cretaceous rift-related upwelling and melting of the Trindade starting mantle plume beneath western Brazil. (accepted for publication, Contrib.Mineral.Petrol, Set./1996), 27p.

GRIEVE,R.A.F. \& ROBERTSON,P.B.,1979. The terrestrial cratering record 1, current staturs of observations. Icarus, 38:212-229.

GROSSI SAD,J.H.;CARDOSO,R.N.;COSTA,M.T.da; 1971. Formações cretácicas em Minas Gerais: uma revisão. Rev.bras.Geoc., 1:2-13.

GROUT,F.F.,1932. Petrography and petrology. McGraw Hill Book Co., N.Y., 522 p.

HABICHT, J.K.A.,1979.Paleoclimate, paleomagnetism and continental drift. Amer.Petrol.Geol.Stud.Geol.,9. 1-31.

HALLAN,A.,1985. A review of Mesozoic climates. J.Geol.Soc.London, 142:433-445.

HALLAN,A.,1986. The Pliensbachian and Tithonian extinction events. Nature, 319:765-768

HARLAND, W.B., ARMSTRONG, R.L., COX, ALV., CRAIG, L.E., SMITH, ALG., SMITH, D.G.,1989. A geologic time scale 1989. Cambridge Univ.Press, 263 p.

HASUI, Y. 1968.A Formação Uberaba. IN: CONGR.BRAS.GEOL., 27, Belo Horizonte, 1968. Anais... SBG, Belo Horizonte, p.167179.

HASUI, Y.,SADOWSKI, G.R., SUGUIO, K. \& FUCK, G.F., 1975. The Phanerozoic tectonic evolution of the Western Minas Gerais State. An.Acad. bras. Ciênc. 47:431-438.

HASUI,K. \& CORDANI,U.G.,1968. Idades K/Ar de rochas eruptivas mesozóicas do oeste mineiro e sul de Goiás. 22 Congr.bras.Geol., Belo Horizonte, p. 139-143.

HASUI,Y \& HARALYI,N.L.E.,1991. Aspectos lito-estruturais e geofísicos do soerguimento do Alto Paranaíba. Geociências 10:57-77.

HASUI,Y \& PENALVA,F., 1970. O problema do diamante do Alto Paranaíba, Estado de Minas Gerais. SBG/SP, Bol.19(1):71-78.

HILDEBRAND, A.R., PENFIELD, G.T., KRING, D.A., PILKINGTON, M., CAMARGO, A.Z., JACOBSEN, S.B., BOYNTON, W.V., 1991. Chicxulub crater: a possible Cretaceous/Tertiary boundary impact crater on the Yucatán Peninsula, México. Geology, 19:867-871.

HOLTZ, M.,1992. Caracterização paleoclimática no Triássico do Gonduana Sul Brasileiro. Acta Geológica Leopoldensia 36, vol. XV, p. 159-160.

HOWELL,D.G.,1985. Terranes. Scientific Amer., 253(5):90-103.

HSÜ, K.J. \& McKENZIE, J.A.,1990. Carbon-isotope anomaly at era boundaries. In: Global Catastrophes in Earth History (eds. V.L.Sharpton and P.D.Ward), pp. 61-70. Geol.Soc.America Spec.Paper no. 247.

HSÜ, K.J., 1992. Is Gaia endothermic? Geol.Mag. 129(2):129-141

HSÜ,K.J. \& McKENZIE,J.A.,1985. A "Strangelove"ocean in the earliest Tertiary, In: Sundquist, E.T. \& Brooks, W.S.,eds. Natural variation Archean to present. Amer.Geoph.Union, Geogr. Monography, 32:487-492.

HSÜ,K.J.,1986. Environmental crisis in times of biotic crisis. In: Patterns and processes in the history of life (eds Raup,D.M.\& Jablonski,O.), p. 297-312. Springer Verlag, Berlin.

HUENE,F.F.von,1942. Die Fossilen reptilien des südamerikanischen gondwanalandes (vertido para o portugues por Júnior, C.B., sob o título Répteis fósseis do Gondwana sul-americano, 1990. CCNE,Depart.Geociências da Univ.Fed.de Santa Maria, Santa Maria, RS,353 p.

HULVER,M.L.;MARKWICK,P.J.; ZIEGLER,A.M; ROWLEY,D.B.,1993. Paleogeography of the Middle JurassicPaleogeographic Atlas Project-Related Research- Houston Geol.Soc.Bul.36:50-52.

HUSSAK, E., 1906. Sobre os diamantes do oeste do Estado de Minas Gerais e imediações dos Estados de São Paulo e Goiás, Brasil. Trad. inédita de J.F.M.R. ALBUQUERQUE, 1990), do original "Uber die diamantlager in Westen des Staates Minas Gerais und der angranzenden Staates São Paulo un Goiyaz, Brasilien" 
Zeitschrift für Praktische Geologie, Jg 14, p. 318-333.

JENKYNS,H.C.,1988. The early Toarcian (Jurassic) anoxic event: Stratigraphic, sedimentary and geochemical evidence. Amer.J.Sci., 288:101-151.

KARFUNKEL,J.\& CHAVES,M.L.S.,1994. Conglomerados cretácicos da Serra do Cabral, Minas Gerais e sua possível relação com os diamantes aluvionares da região. Bol III Simp. sobre o Cretáceo do Brasil, Rio Claro, SP, p. 197-199.

KATTAH, S.da S.,1991. Análise faciológica e estratigráfica do Jurássico Superior/Cretáceo Inferior na porção meridional da Bacia Sanfranciscana, oeste do Estado de Minas Gerais. (Dissertação de Mestrado), UFOP, 227 p.

KATTAH,S.da S.,1994. Ocorrências de pegadas de dinossauros no Grupo Areado, porção meridional da Bacia Sanfranciscana, oeste de Minas Gerais. Anais Acad.bras.Ciên., 66(2):181-187.

KATTAH,S.da.S. \& KOUTSOUKOS,E.A.M.,1992. Ocorrências de radiolários em facies de origem marinha no mesozoico da Bacia Sanfranciscana. Anais VI Simp.Geol.de Minas Gerais, Rev.Esc.Minas 45:214, Ouro Preto.

LADEIRA, E., BRAUN, O.P.G., CARDOSO, R.N. \& HASUI, Y., 1971. O Cretáceo em Minas Gerais. In: CONGR.BRAS.GEOL.,25, São Paulo, 1971. Anais... São Paulo, SBG, p. 15-31.

LADEIRA,E.A. \& BRITO, O.E.A.de, 1968.Contribuiçãoa à Geologia do Planalto da Mata da Corda. 22o Congr.bras.Geol., Belo Horizonte, p.181-199.

LANDIM.P.M.B. \& SOARES, P.C. 1976. Estratigrafia da Formação Caiuá. IN: CONGR.BRAS.GEOL., 29, Ouro Preto, 1976. Anais...Ouro Preto, SBG, p. 195-206.

LARA,R.P.,1993. Mapeamento litoestratigráfico do Mesozóico na borda NE da Bacia do Paraná (região de Ponte Alta-Uberaba). Trabalho Geológico, IGC/UFMG, 57p.

LAVINA, E.L.C.\& FACCINI, 1992. A Formação Pirambóia no Estado do Rio Grande do Sul-um episódio de desertificação ao final do Permiano, início do Triássico. Acta Geológica Leopoldensia, 36, vol.XV, p. 162

LAVINA, E.L.C., 1992. A distribuição mundial dos paleoclimas mesozóicos e as condições gerais de vida terrestre. RS, Acta. Geol. Leopoldensia 36, vol. XV, p. 124-125.

LEONARDI,G. \& LIMA,F.H.O., 1990. A revision of the Triassic and Jurassic tetrapod footprints of Argentina and a new approach to the age and meaning of the Botucatu Formation footprints (Brazil). Rev.Bras.Geoc., 20:216-229.

LEONARDI,G.,1977. Two Ichnofaunas (vertebrates and invertebrates) in the eolian Cretaceous sandstones of the Caiuá Formation in Northwest Paraná. 1o Simp.Geol.Reg., São Paulo, p. $112-128$.

LEONARDI,G.,1980. On the discovery of an abundant ichno-fauna (Vertebrates and Invertebrates) in the Botucatu Formation s.s. in Araraquara, Sao Paulo, Brazil. An.Acad.Brasil.Ciencias ,53(3):559-567.

LEPERSONNE,J.,1951. Les subdivisions de systèmes du Karroo au Kwango(Congo Belge). Ann.Soc.Géol.de Belgique, T. 74, p. 123-139.

LERBEKMO, J.F. \& St.LOUIS, R.M., 1986. The terminal Cretaceous iridium anomaly in Red Deer Valley, Alberta, Canada. Can.J.Earth Sci., 23:120-124.

LERBEKMO, J.F., SWEET, A.R.\& St.LOUIS, R.M., 1987. The relationship between the iridium anomaly and palynological floral events at three Cretaceous-Tertiary boundary localities in Western Canada. Geol.Soc.America Bull., 99:325-330.

LIMA,M.R.,1979. Palinologia dos calcários laminados da Formação Areado, Cretáceo de Minas Gerais. In: Simp.reg.de Geologia, 2, Rio Claro. vol.1, p. 203-216.

LITTLE,C.P.\& BENTON,M.J.,1995. Early Jurassic massextinction: a global long-term event. Geology, 23(6):495-498.

LLOYD, C.R.,1982. The Mid-Cretaceous Earth: Paleogeography:Ocean circulation and temperature:Atmospheric circulation. Journal of Geology, 90:393-413.

MacKENZIE,F.A.,1990. Sedimentary carbonates in the evolution of Earth's surface environments. In Geochemistry of Sedimentary Carbonates. (eds. Morse,J.W. \& MacKenzie F.T.), p. $507-594$.

MAGARITZ,M.;BAR,R.;BAUD,A.;HOLSER,W.T.,1988. The carbon-isotope shift at the Permian/Triassic boundary in the southern Alps is gradual. Nature, 331(6154):337-339.

MANTOVANI,M.S.M., 1995.Denudation,fission track analysis and the long-term evolution of passive margin topography: application to the southeast Brazilian margin. J.South Amer.Earth Sci., 8(1): 65-77.

MANTOVANI,M.S.M., CORDANI, U.G., ROISENBERG,A., 1985. Geoquimica isotopica em vulcanicas acidas da Bacia do Parana e implicacoes geneticas associadas. Rev.Brasil.Geoc., 15:61-65.

MANTOVANI,M.S.M., MARQUES,L.S., DE SOUZA,M.A., CIVETTA,L., ATALLA, L., INNOCENTI, F., 1985. Trace element and strontium isotope constrains on the origin and evolution of Parana Continental Flood Basalts of Santa Catarina State (Southern Brazil). J.of Geology, 26(1):187-209.

MARINI,O.J.; FUCK, R.A.; DARDENNE, M.A.; TEIXEIRA, N.A.,1981. Evolução tectônica da Faixa Brasília e seu embasmento. Anais do Simp.sobre o Cráton do São Francisco e suas faixas marginais.SBG/BA, p. 100-115.

MARINI, O.J.; FUCK, R.A.; DARDENNE, M.A.; TEIXEIRA, N.A.; 1978.Dobramentos da borda oeste do Cráton São Fancisco. Anais reun. preparatória sobre o Simp.Cráton do S.Francisco e suas faixas marginais.Publ.Esp.no.3, SBG/BA, p.155-224.

MAXWELL,W.D.\& BENTON M.J.1987. Mass extinction and data base:changes in the interpretation of tetrapod mass extinction over the past 20 years. In P.J.CURRIE and E.H.KOSTER (eds), 4th Symposium of Mesozoic Terrestrial Ecosystems. Occasional Paper of the Tyrrell Museum of Palaeontology, Alberta, 3:15660.

MAXWELL,W.D.,1989. The end Permian mass extinction.In Mass Extinctions-Process and evidences, STEPHEN K. DONOVAN, ed., 1989., Columbia Univ.Press,p.152-173.

McDOUGALL,I. \& RUEGG,N.R., 1966. Potassium-argon dates on the Serra Geral Formation of South America. Geoch.Cosm.Acta, 30:191-195.

McLAREN,D.L.J.,1983. Bolides and bioestratigraphy. Geol.Soc.America Bull., 93:313-324.

MEDEIROS, R.A., 1992. O Cretáceo no Brasil. Processos, ambientes e fácies sedimentares. Rio S,. Acta Geol.Leopoldensia, vol.XV, no. 36, p. 130-131.

MENDES, J.C.,1951. Estratigrafia e malacofauna da Formação Corumbataí na região do vale homônimo, Estado de São Paulo. São Paulo, FFCL/USP Bol.8.

MESNER, J.C. \& WOOLDRIDGE, L.C.P., 1964. Estratigrafia das bacias paleozóicas e cretácicas do Maranhão. Bol.Técn. Petrobrás, Rio de Janeiro. 7(2):137-164.

MEZZALIRA,S.,1974.Contribuição ao conhecimento da estratigrafia e paleontologia do Arenito Bauru. Inst.Geogr.Geol., Bol.51, 163.p.

MEZZALIRA,S.,1980. Aspectos paleoecológicos da Formação Bauru. IN: Mesa Redonda sobre a Formação Bauru no Estado de São Paulo e regiões adjacentes. Publ. SBG/SP no. 7, p. 114.

MIZUZAKI A.P.M.;THOMAZ FILHO,A.;CÉSERO,P.de; 1996. Magmatism related to the opening of South Atlantic Ocean, 1996. IN: South Atlantic Mesozoic Correlations, IGCP Project n. 381, SAMC News No.5, p.46-47.

MOARES,L.C.de; SEER,H.J.; KATTAH,S.da S.;1987. Aspectos petroquímicos das rochas vulcânicas alcalinas cretácicas da porção meridional da Bacia Sanfranciscana, Minas Gerais. Congr.bras.Geoquim. 1, Porto Alegre, v.1, p. 315-318.

MONTES-LAUAR, C.R.; PACA, I.G.; MELFI, A.J.; PICCIRILLO, E.M.; BELLIENI,G.; PETRINI,R.; RIZZIERI,R.;1994. The Anari and Tapirapuã Jurassic Formations, western Brazil. Paleomagnetism, geochemistry and geochronology. Earth and Planetary Sci. Letters, 128:357-371.

MORAES,L.C.de; SEER,H.J.;FOGACA,A.C.C.;SGARBI,P.B.de; SGARBI,G.N.C.; 1986.Geologia das unidades cretácicas da área compreendida entre Lagoa Formosa e Carmo do Paranaíba, Minas Gerais. 34o.Congr.bras.Geol., Goiânica, v.1, p.337-345.

MORGAN,W.J.,1986. Flood basalts and Mass Extinction.Eos-AGU 67(16):391

MUSA,D.1974. Paleoxiloanatomia Brasileira.I-Protopinaceae da Formacao Botucatu, Minas Gerais, Brasil. An.Acad.Bras.Cienc.,46(3/4):497-513. 
OFFICER,C.B.\& DRAKE,C.L.,1983. The Cretaceous-Tertiary transition. Science, 219(4591):1383-1390.

OLIVEIRA, A.I.de \& LEONARDOS,O.H.,1943. Geologia do Brasil, 2a.edição. Sev.Inf.Agric., Rio de Janeiro, 813 p.

OLIVEIRA, E.P.de.,1936. Madeiras silicificadas do platô dos Parecis. Bol.DNPM, 3, $14 \mathrm{p}$

OLIVEIRA, F.H. \& LEONARDI,G.,1990. A revision of the Triassic and Jurassic tetrapod footprints of Argentina and a new approach on the age and meaning of the Botucatu Formation's footprints (Brazil). Rev.Bras.Geoc., 20(1-4):216-229.

PARRISH, J.T.\& CURTIS,R.L., 1982.Atmosferic circulation upwelling and organic-rich rocks in the Mesozoic and Cenozoic Eras. Palaeogeogr.,Palaeoclimatol.,Paleoecol., 40:31-66.

PARRISH,J.T.,ZIEGLER,A.M.,SCOTESE,C.R.,1982. Rainfall patterns and the distribution of coals and evaporites in the Mesozoic e Cenozoic. Palaeogeog., Palaeoclimatol.,Palaeoecol., 40:67-102.

PEATE D.W., MANTOVANI,M.S.M., HAWKESWORTH C.J.,1988.Geochemical stratigraphy of the Parana Continental Flood Basalts: borehole evidence. Rev.Brasil.Geoc., 18(2):212221.

PEATE,D.W., HAWKESWORTH,C.J., MANTOVANI,M.S.M., 1992. Chemical stratigraphy of the Parana lavas (South America): classification of magma types and their spatial distribution. Bull.Volcanology, 55:119-139.

PEREIRA, L.F., DARDENE, M.A., ROSIÈRE, C.A., PEDROSASOARES, A.C. 1992. Evolução geológica dos Grupos Canastra e Ibiá na região entre Coromandel e Guarda-Mor, MG. 37o Congr.bras.Geol., São Paulo. p.310-311.

PEREIRA,L.F.;DARDENNE,M.A.;ROSIĖRE,C.A.;PEDROSASOARES,A.C.;(1994). Evolução geológica dos Grupos Canastra e Ibiá na região entre Coromandel e Guarda-Mor,MG. Geonomos,2(1):22-32.

PERUZZO,C.S. \& SCHULTZ,C.L.,1992. Relações entre a paleogeografia, paleoclimatologia e algumas mudanças faunísticas ocorridas no Gondwana no Triássico Médio.Acta Geol.Leopoldensia v.XV no.36, p.161.

PESSAGNO,E.A.Jr.;DIAS-BRITO,D.,1996. O silexito a radiolário do sul da Bacia Sanfranciscana, Brasil. Idade, origem, significado. Bol IV Simp.sobre o Cretáceo do Brasil, Rio Claro, Unesp, p. 213-221.

PETRI,S. \& CAMPANHA, V.A., 1981.Brazilian continental Cretaceous.Earth Science Review,17:69-85.

PETRI,S. \& FULVARO,V.J.,1981. Geologia da Chapada dos Parecis, Mato Grosso, Brasil. Rev.bras.Geociências, 11(4):274282.

PETRI,S., 1991 Paleogeografia do Cretáceo do Brasil e considerações sobre o paleoclima. Geociências, 10:1-35

PETRI,S.,1955. Charophytas cretácicas de São Paulo (Formação Bauru). Soc.bras.Geol., Bol.4(1):67-72.

PETRI,S.,1983. Brazilian Cretaceous paleoclimates: evidences from clay-minerals, sedimentary structures and palynomophs. Rev.bras.Geoc., 13(4):215-222.

PICCIRILLO,E.M., BELLIENI,G.,CAVAZZINI,G.,COMINCHIARAMONTI,P., PETRINI,R., MELFI,A.J.,PINESE,J.P.P., ZANTADESCHI,P., DE MIM,A., ,1990. Lower Cretaceous tholeiitic dyke swarms from the Ponta Grossa Arch (Southeast Brazil): Petrology, Sr-Nd isotopes and genetic relationship with the Parana flood volcanics. Chemic. Geology, 89:19-48.

PIMENTEL,M.M.;FUCK R.A.;ALVARENGA,C.J.S.de, 1996. PosBrasiliano (Pan-African) high K granitic magmatism central Brazil: the role of Pre-Cambrian/Early Proterozoic extension. (46 p., no prelo).

PINTO FILHO F.P., FREITAS, A.F.de, MELO, C.F.de, ROMANINI, S.J., 1977. Projeto Sudeste de Rondônia. Porto Velho, DNPM/CPRM, v.1.

PINTO,I.D. \& ORNELLAS,L.P.,1974. A new insect Triassoblatta cargnini Pinto et Ornellas, sp.vo., a Triassic Blattoid from Santa Maria Formation, South Brazil. An.Academ. bras.Cien., 46(3/ 4):515-521.

PIRES,F.R.M.,1982. Formação Bauru: Controvérsias. Anais. Acad.bras.Ciên., 54(2):369-393.

PITAKPAIVAN,K.;BYERLY,G.R.;HAZEL,J.E., 1994. Pseudomorphs of impact spherules from a Cretaceous-Tertiary boundary section at Shell Creek, Alabama.Earth
Plan.Sci.Letters, 124:49-56.

PITMAN,W.C.\& GOLOVCHENKO,X.,1991.The effect of sea level changes on the morphology of mountains belts. Journal of Geoph.Research, 96:6879-6891.

POTTER,P.E.,1994. Modern sands of South America: composition, provenance and global significance. Geol.Rundsch., 83:212232.

PRICE, L.I., 1950. Os crocodilídeos da fauna da Formação Bauru do Cretáceo terrestre do Brasil Meridional. An.Acad.Bras.Ciênc., 22(4):473-490.

PRICE, L.I.,1953. Os quelônios da Formação Bauru, Cretáceo terrestre do Brasil Meridional. Bol DGM, DNPM (147):1-39.

RAMPINO,M.R \& STOTHERS,R.B.,1988. Flood basalt volcanism during the past 250 million years. Science, .241: 661-668.

RAUP,D.M.,1979. Size of the Permo-Triassic bottleneck and its evolutionary implications. Science, 206(4415):217-218.

RENNE,P.R.,ERNESTO,M.,PACCA,I.G., COE, R.S., GLEN, J.M., PREVOT,M., PERRIN,M.,1992. The age of Parana Flood Volcanism, rifting of Gondwanaland, and the JurassicCretaceous boundary. Science, 258:975-979.

RICCOMINI,C., 1996. Tectonics of the Bauru Basin in the State of São Paulo. IN: South Atlantic Mesozoic Correlations, IGCP Project n. 381, SAMC News No.5, p.79-80.

RICHARDS, M.A., DUNCAN, R.A., COURTILLOT, V.E.,1989. Flood basalts and Hot-Spot tracks: plume heads and tails. Science 246:103-107.

RICOMINNI,C.;GIMENEZ FILHO,A.;ALMEIDA,F.F.M. de, 1984. Considerações sobre a estratigrafia do permo-triássico na região da Serra do Cadeado, Paraná. 28o.Congr.bras.Geol., Rio de Janeiro, v.7, p. 754-763.

RIVAROLA, D. \& Di PAOLO, E. (1992) Secuencias mesozoicas da la Sierra de Las Quijadas. Paeoambientes y Paleoclimas. Provincia de San Luis, Republica Argentina. Acta Geológica Leopoldensia 36, vol.XV, p. 143-145.

ROCHA-CAMPOS,A.C., CORDANI,U.G., KAWASHITA,K., SONOKI,H.M., SONOKI,I.K.,1988. Age of the Parana flood volcanism In: PICCIRILLO,E.M.\& MELFI,A.J (eds) The Mesozoic flood volcanism of the Parana Basin: Petrogenetic and geophysical aspects. IAG-USP press, p. 25-46.

ROHN,R. \& RÖSLER, O., 1990. Conchostráceos da Formação Rio do Rasto (Bacia do Paraná, Permiano Superior):bioestratigrafia e implicações paleoambientais. Rev.Bras.Geoc., 19(4):486-493.

RUNMEY,G.R., 1968. Climatology and world's climate. MacMillan Co., 656., London.

SAAD.R.A.; CAMPANHA,V.A.; CABRAL Jr., M.C.; ETCHEBEHERE, M.L.de C.; FILHO, P.P.; MOTA, J.F.N.; SILVA,F.de P.;1988. Cenários do Grupo Bauru (K) no Estado de São Paulo. 35o.Congr.bras.Geol., Belém, v.2, p. 894-901.

SALGADO-LABOURIAU, M.D.,1994. História ecológica da Terra. Edgar Blücher, São Paulo, 307 p.

SANTOS,R.da S.,1983. Laeliichthys ancestralis, um novo gênero e espécie de osteoglossiformes do Aptiano da Formação Areado, Estado de Minas Gerais, Brasil. VII Congr. bras.Paleontologia, p.161-167.

SCHMIDT, K. \& BÖGEL, H., 1976. Kleine Geologie der Ostalpen. Otto Verlag Thun, $231 \mathrm{p}$.

SCHMIDT,W.,1983. Die Geologie des Araxá Gruppe in Sudwest Minas Gerais, Brasilien unter besonderer Berücksichtigung des Grünsteingürtels von Fortaleza de Minas. Tese de Dotorado, Univ. Albert Ludwing-Univ.Freiburg, $134 \mathrm{p}$.

S C H N E I D E R, R. A .; M U H L M A N N, E .; TOMASI,E.;MEDEIROS,R.A.;DAEMON,R.F.; NOGUEIRA,A.A.; 1974. Revisão estratigráfica da Bacia do Paraná. 28o. Congr.bras.Geol., Porto Alegre, p. 41-65.

SCHOBBENHAUS, C., ALMEIDA-CAMPOS, D.de, DERZE,G.R., ASMUS, H.E.A. (Editores), 1981. Mapa Geológico do Brasil.Esc. 1:2 500000

SCHULTZ,C.L.\& AZEVEDO,S.A., 1990. Dados preliminares sobre a ocorrência de uma nova forma de rincossauro para o Triássico do Rio Grande do Sul-Brasil. Paula-Coutiana (4):35-44.

SCORZA,F.P. \& SANTOS, R.da S.,1955. Ocorrencia de folhelho fossilífero no município de Presidente Olegário, Minas Gerais. Rio de Janeiro, DNPM/DGM, Bol. 155, 27 p.

SCOTESE,C.R.,1993. Paleogeographic maps In: Geochronology The interpretation and dating of the geological record. The New 
Encyclopaedia Britannica, Chicago, $15^{\text {th }}$ ed. p.748-876.

SEPKOSKI,J.J.,1984. A kinetic model of Phanerozoic taxonomic diversity. III Post-Paleozoic families and mass-extinction. Paleobiology, 10(2):246-267.

SGARBI, G.N.C., 1989. Geologia da Formação Areado, Cretáceo Médio a Inferior da Bacia do São Francisco, oeste do Estado de Minas Gerais. (Dissertação de Mestrado), UFRJ, 324.

SGARBI, G.N.C., 1991a. Geologia dos sedimentos lacustres da Formação Areado, bacia cretácica do São Francisco. Atas do II Simp.Geol.Sudeste, São Paulo, SBG/SP-RJ, p. 67-75.

SGARBI, G.N.C., 1992. A disconformidade entre a Fm. Areado e Fm. Mata da Corda, Bacia cretácica do São Francisco, MG. Resumo Exp., Acta Geol.Leopoldensia, v.15, no. 36, p.134136.

SGARBI, G.N.C., HORN, A.H., GROSSI SAD, J.H., 1993. Aspectos químicos e isotópicos dos sedimentos lacustres da Formação Areado, bacia do São Francisco, MG. An.Acad. bras. Ci., 65(3):266-270

SGARBI, P.B.de A. \& VALENÇA, J.G., 1991. Petrography and general chemical featuares of potassic mafic to ultramafic alkaline volcanic rocks of Mata da Corda Formation, Minas Gerais State, Brazil. Ext.Abs., Fifth Intern.Kimberlite conference, Araxá, p. 355-360.

SGARBI, P.B.de A. \& VALENÇA, J.G., 1993. Kalsilite in Brasilian kamafugitic rocks. Min.Mag., 57:165-171.

SGARBI,G.N.C. \& DE ROS, L.F.,1995b. Petrological and chemical aspects of K-feldspar authigenesis lin the Cretaceous Areado Sandstones, São Francisco Basin, Central Brasil. Geociências, 14(1):97-117.

SGARBI,G.N.C. \& LADEIRA, E.A.,1995a .Ventifacts of Cretaceous Proterozoic unconformity Alto do Paranaíba Region, west of Minas Gerais State, Brazil. Geociências 14(1):119-151.

SGARBI,G.N.C., 1991b. Arenitos eólicos da Formação Areado (Bacia Cretácia do São Francisco): caracterização, diagênese e aspectos químicos. Rev.bras.Geoc., 21(4):342-354. (no prelo).

SGARBI,G.N.C., 1996b.Spatial relationships in Cretaceous sequences at NNE border of the Paraná Basin. IV Simp. sobre o Cretáceo do Brasil, Unesp, Rio Claro, p. 225-228.

SGARBI,G.N.C.,1996a. General aspects of the São Bento Group, Paraná Basin: A bibliographic research. IV Simp.sobre o Cretáceo do Brasil, Unesp, Rio Claro, p. 239-245.

SGARBI,G.N.C.,1996c. Microanálises em piroxênios e suas implicações com a proveniência dos vulcanoclastos da Formação Uberaba do Grupo Bauru, oeste do Estado de Minas Gerais.(estudo em preparação).

SGARBI,P.B.de A., 1991c. Petrografia e geoquímica da Formação Mata da Corda na região de Carmo do Paranaíba, MG. Tese de Mestrado, UFRJ,214p.

SHAND,S.J.,1969. Eruptive rocks. Hafner Pub.Co., N.Y., 488 p.

SILVA,R.B.da; ETCHEBEHERE,M.L.C.;SAAD,A.R.;1994. Ground-water calcretes: uma interpretação alternativa para os calcretes da Formação Marília no Triângulo Mineiro. Bol. III Simp.sobre o Cretáceo do Brasil., Rio Claro, p. 85-89.

SOARES, P.C. \& ASSINE, M.L., 1992. A sequência triássicojurássica da Bacia do Paraná. Acta Geológica Leopoldensia 36, vol. XV, p. 137-139.

SOARES, P.C. \& LANDIM,P.M.B., 1975. Quaternary deposits in South-Central Brazil interior: Internat.Symp.Quaternary Abstrac., Bol.Paran.Geoc.no.33:17.

SOARES, P.C., LANDIM, P.M.B., FÚLFARO, V.J.\& NETO, A.F.S., 1980. Ensaio de caracterização estratigráfica do Cretáceo no Estado de São Paulo: Grupo Bauru. Rev.Bras.Geoc., 10:177-185.

SOARES, P.C.,1975. Divisão estratigráfica do Mesozóico no Estado de São Paulo. Rev.bras.Geoc.5(4):229-51.

STINNESBECK, W., ABDUL, R.A. \& PERCH-NIELSEN, K.S., 1991. Estudos paleontológicos no limite Cretáceo-Terciário no Estado de Pernambuco. Univ. Fed. de Pernambuco, Estudos e Pesquisas n.10, série B, p. 141-156.

SUGUIO, K. \& BARCELOS, J.H., 1983. Paleoclimatic evidence from the Bauru Group, Cretaceous of the Paraná Basin, Brazil. Rev.Bras.Geoc., 13(4):232-236.

SUGUIO, K., BARCELOS, J.H. \& MONIZ, A.C., 1976 Caracterização sedimentológica e mineralógica de formações superficiais argilo-arenosas peculiares dos planaltos do Triângulo Mineiro e Alto Paranaíba, MG. IN: CONGR.BRAS.GEOL., 29, Ouro Preto, 1976. Anais...Ouro Preto, SBG, v.2, p.241-247.

SUGUIO,K.,1996. The Brasilian Cretaceous climates in the context of global climatic changes. IV Simp. sobre o Cretáceo do Brasil, Unesp, Rio Claro, p. 257-260.

THEILEN-WILLIGE, 1981. The araguainha impact structure/central Brazil. Rev.Bras.Geoc., 11:91-97.

TOMPKINS,L.A. \& GONZAGA,G.,1989. Diamonts in Brazil and a proposed model for the origin and distribution of the diamonts in Coromandel region, Minas Gerais, Brazil. Econom.Geol., 84:591-602.

TORQUATO,J.R. \& CORDANI,U.G.,1981. Brazil-Africa geological links. Earth Sci.Review, 17:155-176.

TURNER,S., REGELOUS,M., KELLEY,S., HAWKESWORTH,C., MANTOVANI,M.,1994. Magmatism and continental break-up in the South Atlantic: high precision 40Ar-39Ar geochronology. Earth and Planet.Sci.Letters 121:333-348.

ULBRICH,H.H.G.J.\& GOMES,C.B.,1981. Alkalines rocks from continental Brazil. Earth Sci. Reviews, 17:135-154.

VAZ DE MELO, M.T. et al., 1994. Mapa geológico do Estado de Minas Gerais, Belo Horizonte, Comig, esc. 1:1 000000.

VOLK, T., 1989. Rise of angiosperms as a factor in long-term climatic cooling. Geology, 17:107-110.

WARD,W.C.;KELLER,G.;STINNESBECK,W.;ADATTE,T.;1995. Yucatán subsurface stratigraphy: implications and constrains for the Chicxulub impact. Geology, 23(10):873-876.

WEISSERT, H. \& LINI A., 1991. Ice age interlude during times of Cretaceous greenhouse climate - a Tethyan perspective. In: Controverses in Geology (eds. D.MÜLLER, J.A.McKENZIE and WEISSERT, H.), pp.173-92. London, Academic Press.

WENZ,S.,1975. Un nouveau coelancathidé du Crétacé Inférieur du Niger, remaques su la fusion des os dermiques. Colloque Int. C.N.R.S., 218, p. 175-190.

WENZ,S.,1980. A propos du genre Mawzonia Coelacanthe géant du Crétacé Inférieur d'Afrique et du Brésil. Ecosystemes continentau du Mèsozoic. Mem.Soc.Géol.Fr., 139, p. 187-190.

WENZ,S.,1981. Un coelacanth géant Mawzonia lavocati Tabaste de l'Albien, base du Cénomanian du Sud du Marocain. Annales de Paléontologie des Vértebrés, Masson, Paris, v.67, fasc.1, p. 120.

WESKA,R.K.;DANNI,J.C.M.;DARDENNE,M.A.;PERIN,A.L.; 1988. Contribuição à estratigrafia do Grupo Bauru na região da Chapada dos Guimarães-MT. 25o.Congr.bras.Geol., Belém, v.2, p. 905-915.

WES KA,R.K.; S VISERO,D.P.; LEONARDOS,O.H .; 1996.Contribuição ao conhecimento do Grupo Bauru no Estado de Mato Grosso, Brasil. IV Simp. sobre o Cretáceo do Brasil, Rio Claro,p.. 289-295.

WIENS,F.,1986. Zur lithostratigraphischen, petrographischen und strukturellen Entwicklung des Rio Apa-Hochlandes, NordostParaguay.Clausthaler Geowiss.Diss.Nr.19,280p.

WILSON, J.L.,1975. Carbonate facies in geologic history. Springer, NEW YORK.

WINDLEY,B.F., 1979. The evolving continents. John Wiley \& sons, Bristol, p. 277-295.

ZALAN, P.V., WOLFS, S., CONCEICAO, J.C. DE J., ASTOLIFI, M.A.M., VIEIRA, I.S., APPIS,V.T. \& ZANNOTTO,O.A., 1987. Tectonic and sedimentation in the Parana Basin. Anais 3o.Simpos.Sul Brasileiro Geol., Curitiba, p. 30-33.

ZIEGLER,A.M.,1993. Models come in from the cold. Nature, 361:16-17.

ZIEGLER,A.M.;HULVER,M.L.;ROWLEY.D.B.,1996. Permian world topography and climate (in press) 